\title{
A kaposvári vár
}

\author{
MOLNÁR ISTVÁN \\ Rippl-Rónai Megyei Hatókörű Városi Múzeum, H-7400 Kaposvár, Fő út 10., \\ e-mail: molnaristvan74@yahoo.com
}

MOLNÁR, I.: The Castle of Kaposvár.

Abstract: Within the scope of this study I give a short account of the major scources and of the excavation led in 2019 at the Kaposvár Castle. I try to determine the building periods of the castle and its dimensions.

Keywords: mediaval castle, post mediaval castle, palisade wall

Kaposvár egykori vára sajnos nem tartozik a sokat kutatott erősségek közé. A jórészt megsemmisült vár helyén gyárak épültek, így régészeti feltárásra kevés lehetöség volt, a történetírás is viszonylag keveset foglalkozott a várral. Az elmúlt években ugyanakkor nem csak a vár történetének kutatásában történt elörelépés, de 2019 tavaszán régészeti feltárást végezhettünk a romoknál. Mivel az ásatásról már jelentek meg beszámolók, ${ }^{1}$ most csak röviden foglalom össze a munka eredményeit. Ugyanakkor úgy vélem - egy reménybeli hosszabb, a leletanyagot is ismertető tanulmány elött is - célszerü áttekinteni a várral kapcsolatos fontosabb forrásokat, a rendelkezésünkre álló információkat és a felmerülő kérdéseket ${ }^{2}$. A kézirat leadási határideje után, 2020 júliusában újabb feltárásra nyílt lehetőség, amely eredményeit csak néhány szóban ismertetem.

\section{A történeti adatok}

A vár középkori történetéről az elmúlt évtizedekben megjelent hosszabb-rövidebb összefoglalások után ${ }^{3}$ Tímár Péter 2016-os könyvében olvashatunk terjedelmes áttekintést. ${ }^{4}$ Magam csak néhány, a vár építéstörténete szempontjából is fontos eseményre szeretnék kitérni.

A kaposvári várra vonatkozó első adatként három évszám is szóba került az elmúlt évtizedekben. A kérdés tisztázása azért is fontos, mert jelentősen befolyásolja a vár és a legkorábbi részének számító lakótorony keltezését is. A vár első említéseként sokáig egy 1359-es adat szerepelt, amely valójában Kapuvárra vonatkozik. ${ }^{5}$ Többször egy 1348-as oklevelet is a későbbi Kaposújvárhoz kapcsoltak, ${ }^{6}$ de ez talán a mai Zselickisfaludnál egykor álló Rupolyvárról szólhat. A vár első biztos említése így egy 1387-

1 A feltárásról: Molnár 2019., Molnár 2020.

2 Ezúttal is köszönöm Aradi Csilla segítségét.

3 Zádor 1964. 42-44., Komjáthy 1975., Szakály 1975., Fügedi 1977. 183-184, Engel 1996. I. 336., Magyar 2004. 68-71.,

4 Tímár 2016. 107-125.

5 Komjáthy 1975. 77. A forrás helyes értelmezéséröl Tímár 174175, 95. lábjegyzet

6 Fügedi 1977. 183. es irat, amelyben hatalmaskodások kapcsán említik Újvár (Wywar) castellanusat, ${ }^{7}$ Bako fia Jánost.

A várat birtokló családot ekkoriban Rupolyinak nevezeték. ${ }^{8} \mathrm{~A}$ birtokos családnak is nevet adó település a mai Zselickisfaludnál lévő Ropoly-pusztánál feküdt. Rupoly egy jelentős méretű, a Kapostól északra is átnyúló, de nagyobb részt a folyótól délre, a Zselic erdőségeibe eső birtok központja volt. Az itt azonosított nagyméretű várnál feltárás nem folyt, így pontos korát és eredeti funkcióját nem lehet biztosan megállapítani. A területen még megfigyelhető föld-fa szerkezetű sáncok miatt felmerül államalapítás kori eredete is. 1230ban már biztosan állt, hiszen a mellette lévő patak a „vár vizeként" szerepel. Mivel a patak korábban kaphatta nevét, adat magában még nem bizonyítja a vár folyamatos müködését. 1313-ban Monoszloi Gergely fia Egyed a több településből álló nagybirtokot Rupolyról nevezte meg, feltehetően Rupolynál lehetett a birtok központja, a birtokos lakhelye és valószínűleg vára is.

A Monoszlói Egyedtől a birtokot megosztva Nyéki Lőrinc és Gutkeled nembeli Amadé fia Miklós kapta meg. A Kapos melletti Újvár (a későbbi Kaposújvár) megépítésének okaként felmerült, hogy Miklós a birtok vár nélküli részét szerezte volna meg, így kénytelen volt új várat építeni magának. ${ }^{9}$ Ennek ellentmond, hogy a későbbiekben Rupolynál csak Amádé fia Miklós és leszármazottai szerepelnek, a Nyékieket többé nem említik, talán elcserélhették birtokaikat. ${ }^{10}$ Magát a Rupolyi várat, pontosabban annak castellanusát 1348-ban említik. ${ }^{11}$

Amadé fia Miklóst és családját a kutatás Felsőlendvaiként említi, a Rupolyi birtokkal kapcsolatos korabeli oklevelekben - ha kapnak is jelzőt - Lendvaiként szerepelnek (pl 1348-ban Lendvai bán fia Miklós). 1359-ben, a család kihalása után folyó örökösödési per kapcsán említik az akkor már régen halott Rupolyi Omádé fia Miklóst. Magam korábbi adatot nem ismerek a család Rupolyiként való megnevezésre.

7 A várnagy szó modern kifejezés, az újabb kutatások szerint a latin castellanus magyar megfelelője a porkoláb volt, (Szatlócki 2016a. 139-149.) az egyszerüség kedvéért a latin kifejezést használom.

8 A vár és a család írása az oklevelekben sem teljesen következetes, Rupul, Rupol, Rupolch, Rwpol alakok is előfordulnak. Helynévként Ropolyként, Ropoként örződött meg, a történeti irodalomban Ropoly, Rupoly, Rupol, Rupul alakban is hivatkoznak rá. Magam korábban az oklevelekben leginkább szereplő Rupol alakot használtam, most - a káoszt fokozandó - a kiejtéshez talán közelebb álló Rupolyi alak mellett döntöttem.

9 Fügedi 1977. 183.

10 Tímár 2016. 91.

11 A Rupolyi várról: Győrffy 1975 68. Komjáthy 1975 76., Magyar 1988. 11-13. Magyar- Nováki 2005. 152-153., 252. Tímár 2016. 84-92., 160-162.,) 
A Monoszlóiak kihalása után birtokaik jó része a Vásári Tamáshoz, Miklós esztergomi érsek testvéréhez került. Az oklevelekben Vásári Tamást legtöbbször csak, mint Miklós érsek fivérét említik, a fiai említésekor kerül elő az oklevelekben a Rupolyi előnév, apjukra vonatkoztatva is. 1387-ben az elkövetett hatalmaskodások kapcsán a fiúk mint „Miklós néhai esztergomi érsek fivérének Rupolyi Tamás mesternek fiai, István és János" szerepelnek, ekkor Bako fia Jánost mint Újvár (Wywar) castellánusát említik. Az ekkor említett hatalmaskodás résztvevői, mivel háromszori felszólításra sem jelentek meg a bíróság előtt, következő évben egy fej és jószágvesztési ítéletet is kiharcoltak maguknak. Az egyik idézésben Bakau fia János újra, mint Újvár (Wyuar) castellanusa szerepel. 1394-ben, mivel az elkövetők a károsultaknak elégtétel adnak, felmentették őket, ekkor Bakow fia János Rupoly castellanusa, István és János továbbra is, mint Rupolyi Tamás mester fiai szerepelnek. ${ }^{12}$

A Rupolynál fekvő államalapítás korinak tartott föld-fa szerkezetű vár, a Rupolyinak nevezett legkésőbb a 14. század első felében, de valószínüleg már a 13. században müködő, földesúri tulajdonban lévő „magánvár” illetve a forrásokban 1387-ben megjelenő Újvár kapcsolata számos kérdést vet fel. Véleményem szerint az a legvalószínűbb, hogy volt egy időszak a 14. század végén, amikor a két erősség, a Zselicben lévő régi Rupolyi vár és a Kapos melletti Újvár egyszerre létezett. Ebben az esetben - a még müködő vagy már korábban felhagyott - régi, nagyméretü Rupolyi várat valamikor átalakíthatták a kor igényeinek megfelelöen. ${ }^{13}$ Esetleg gondolhatunk a közelben kialakított másik várra is. Mindenesetre, ha az 1348-as és az 1394-es Rupolyi várat említő oklevelek a Zselicben lévő várról tudósítanak, akkor a Kapos menti Újvárnak az 1387-es oklevélben találjuk az első említését.

$A z$ a lehetőség is felvetődött, hogy a Rupoly nevet már a Kapos melletti várra használták volna a 14 . század közepén. A Rupoly név eredetileg biztosan a Zselic melletti várra vonatkozott, hiszen helynévként is ott őrződött meg, a hasonló nevű település is ott feküdt a középkorban. Nehezen magyarázható, hogy az elnevezés miért került volna át a közel 10 kilométerre északabbra lévő várra. Ha mégis ezt a lehetőséget fogadnánk el, úgy 1348-es említést kellene a későbbi Kaposújvári vár első említésének tartani, míg az 1387es adat a közben megújult várról szólhatna.

Az Újvár, Rupojújvár név eredete is magyarázatra szorul, nem egyértelmű mihez képest lenne „új” a vár. Általában úgy magyarázták, hogy ez család „újabb” vára, ami a korábbi, Rupolynál lévő régi várhoz képest számított újnak. Gondolhatunk arra is, hogy a várnak volt valamilyen közvetlen előde, akár egy forrásokban nem említett, egyszerü, fából készült toronyvár. Mindenesetre nyoma ennek nem maradt meg.

12 Az iratok kivonatát hivatkozásokkal közli Tímár 2016. 445-448.

13 Gondolhatunk arra, hogy pl. a nagyméretü vár sarkát árokkal levágták és oda lakótornyot építettek. A felmérés során nem találtak erre utaló jelet, a területen régészeti feltárás még nem folyt.
A család mindenesetre nem sokáig örülhetett várának. 1403-ban a Zsigmond elleni lázadásban való részvételük miatt az akkor Rupolyújvárként említett várat a család egyéb birtokaival együtt elkobozták. A család tagjait a sorozatban készülő birtokaikat elkobzó és eladományozó oklevelekben még főleg Rupolyiként, néhol (Szlavoniai birtokaik kapcsán) Alsólendvaiként említik, de a Rupolyujvári vár és a hozzá tartozó birtokok kapcsán Rupolyújváriként szerepelnek. ${ }^{14} \mathrm{Ez}$ jó példája annak, hogy a nemesi famíliák megnevezése egy adott időszakban is oklevélröl-oklevélre változhatott, sokszor az adott jogügylethez kapcsolódó helyszín alapján. ${ }^{15} \mathrm{Ez}$ esetünkben azért is érdekes mert a Rupolyi, Rupolyújvári elnevezésekből történeti következtetéseket igyekeztek levonni. ${ }^{16}$ A Rupulwywar elnevezés csak ekkor és 1304-ben, az új tulajdonosok birtokon belülre kerülésekor fordul elő, a vár megnevezése ezután is Újvár. A „régi” Rupolyvárról sem hallunk többet.

$\mathrm{Az}$ uradalom fele-fele arányban a Tamási és a Szerdahelyi családhoz került. Nem tudjuk ki költözött a várba, annyi biztos, hogy 1442-ben Tamási Henrik a várban tartózkodott. A várat 1426-ban, majd az 1440es években többször is következetesen Újvárként (Wywar) említették.

Tamási Henrik halála után, 1445-re a várat Újlaki Miklós szerezte meg. Először egyszerüen rátette a kezét, majd később hivatalosan, királyi adományként is birtokába került az egykor Tamásiak kezén lévő birtokrész. A Szerdahelyiek elvileg tovább birtokolták az uradalom másik felét, de Újlakiék nem engedték őket a várhoz. Újlaki legjelentősebb birtokai a Balatontól északra, Fejér megyében, valamint Szlavóniában feküdtek, és a Macsói bánságnak is ura volt. Északi és déli területeit Somogy megyei birtokai kötötték össze, a kaposvári vár ezért kulcsfontosságú lett számára. ${ }^{17}$ Újlaki fontos központját alakította itt ki, a várat is nyilván fejlesztette, építette. Egy 1459-ben a Szerdahelyiek közeli báti kastélya ellen elkövetett támadás során az elkövetők között Újlaki castellánusait, azok familiárisait, számos fegyverest és cseh zsoldost említenek. Ekkorra a kaposújvári vár már nyilván jelentősen kiépített, viszonylag sok ember befogadására alkalmas erősség volt.

A várat először Újvárnak, de 1465-ben és 1470-ben már Kaposújvárnak (Kaposwywar) nevezték, feltehetően Újlaki másik Újvár nevű várától akarták megkülönböztetni. 1495-ben került sor a vár első ostromára, ekkor a II. Ulászlóval dacoló Újlaki Lőrinc elleni hadjárat során a királyi csapatok elfoglalták a várat. Bonfini leírása szolgáltatja az első adatokat a vár szerkezetéről, figyelemre méltó, hogy hármas árokrendszert és sáncokat említett.

Az 1504-ben az Újlakival megkötött egyezmény után a Szerdahelyiek költöztek be a várba. Az Újlaki család 1524-ben kihalt, birtokrészükért ezután a Szerdahelyiek

14 Az iratok kivonatát hivatkozásokkal közli Tímár 2016. 457-460.

15 Feld 2014. 363

16 Engel Pál Felsőlendvai Miklós utódaihoz a Rupolyi elnevezést és Rupolyi várat, a Vásáriakhoz a Rupolyújvári nevet és Rupolyújvári várat kötötte. (Engel 1996. 326.)

17 Kubinyi 1973. 9. 
a Tóti Lengyel családdal pereskedtek. Az 1543-as török hadjárat után a kaposújvári vár a határra került, és a határvédelem egyik fontos pontja lett. Az 1540-es évekből már vannak adatok itt állomásozó nagyobb létszámú mezei katonaságról, ${ }^{18}$ részükre egy nagyobb területet bizonyára palánkfallal kellett övezni.

A vár 1555 szeptemberében került török kézre, az újabb kutatásokból alapján nem a korábban gondolt gyors kapituláció, hanem véres és viszonylag hosszú ostrom, a védők egy részének igen hősies, halálukig tartó védekezése rajzolódott ki. ${ }^{19} \mathrm{Az}$ ostromkor települést nem említettek, két árokról és két palánkról írnak. 1556-ban egy keresztény ellentámadás miatt a várat a török kiürítette, de 1557-ben újra megszerezte és tartósan berendezkedett. Komoly visszafoglalási kísérlet 1599-ben, a tizenöt éves háború során történt, a vár 1686 novemberében szabadult föl.

A vár pusztulása több szakaszban történt. Az 1702es várrombolási rendelet után legfeljebb a palánkokat rombolhatták. ${ }^{20} \mathrm{~A}$ 18. század elején az Eszterházy család majorsága épült ki az egykori vár területén. A vár külső falainak jó része hamar elbontásra kerülhetett, de az 2019-ben végzett régészti feltárások is igazolták, hogy a középkori vár nyugati palotaszárnyát használatba vették ekkor. A vár természeti környezete a folyó szabályozásával teljesen átalakult, az egykori vizesárkoknak sem maradt semmi látható nyoma. Az újabb súlyos pusztítás az 1930-as években történt, amikor a Nostra nevű gyárépület a vár közepébe építették. Az 1930-as évektöl így már csak a várudvaron álló öregtorony és az északkeleti saroktorony 1-1,5 m magas maradványai, valamint a belső várfalak csekély magasságú részletei voltak láthatóak, amelyekre müemlék téglákkal rá is falaztak. Sajnálatos módon a gyárépülethez vezető ipari vágányt a torony maradványain vezették át. A 20 században újabb üzemek, épületek rombolták a területet.

\section{Újkori térképek}

A vár egykori földrajzi környezetének és elhelyezkedésének rekonstruálásához a 18-19. századi térképek is segítséget nyújtanak. Az ezeken ábrázolt természeti viszonyok természetesen nem feleltethetőek meg teljesen egészében a középkoriaknak vagy a kora újkorinak, de a mai állapotnál mindenképpen jóval közelebb állnak hozzá.

Nagyon hasznos ebből a szempontból egy 1778as vízrajzi térkép, ${ }^{21}$ amelyen egy ívelt vizesárokkal kettévágott szigetet láthatunk, az egyik darabja nagyjából lekerekített négyzet, a másik kifli alakú (1. ábra). A nyugati szigetdarabon épületek látszanak, amelyek közül a legnyugatabbi a vár palotaszárnyának bizonyult a feltárások során. A Kapos a vártól északra ágazik ket-

18 Szatlócki Gábor közlése, segítségét és tanácsait ezúttal is köszönöm.

19 A vár ostromáról Szatlócki 2016.

20 Oross 2005. 98.

21 https://maps.hungaricana.hu/hu/MOLTerkeptar/4678/view/?pg=2\& fbclid=IwAR0e6MvcuqHjL6p3pCSyDBAmyJxu017Bq3zTOwBZv5 BMxr03XRgpXu841vU\&bbox=-741\%2C-6603\%2C10210\%2C-143 té, az egyik ág a szigetet vágja át, ez lehet az egykori vizesárok maradványa, amely fölött híd köti össze a sziget két részét. A Kapos másik ága a szigetet keletről kerüli és választja el a szárazföldtöl. Itt egy hosszabb töltés látható, amelynél két hidat alakítottak ki, a nyugatabbi alatt folyik a Kapos főága. Még keletebbre, a keletebbi híd alatt folyik át egy északról érkező vízfolyás, a mai Malomárok előde. A vizek körül kiterjedt mocsárvilág van ábrázolva.

A vártól nagyjából 1,7 km-re északnyugatra, a folyó felsőbb folyásánál a Keceli malom van jelölve, ahol egy gát és egy átjáró is van a folyón. $1 \mathrm{~km}$-re délkeletre, lentebb a Kaposon a Gilitzei malom felirat látható, szintén egy gáttal és átjáróval. Feltehetően az itteni gátakkal is szabályozhatták a török időkben és talán már a középkorban is a mocsár szintjét. Ezen a két helyen már a középkorban is átkelési lehetőség volt a folyón, itt lehetett a Keceli és az Omaki vám, amelyek a vár tornyából jól megfigyelhetőek voltak.

A folyó szabályozása előtt (1782-85 között) készült első katonai felmérés térképen hasonló képet láthatunk $^{22}$ (2. ábra). Itt is ketté van osztva a sziget, körülötte mocsaras, zsombékos terület van ábrázolva. A vár palotaszárnya itt is látszik, a hidak is ott állnak, ahol az előző térképen. A Kapos folyó ábrázolása is hasonló, a vártól északra ágazik ketté. Az előző térképhez képest annyi a különbség, hogy itt a Kapos keletebbi ágába folyik be az északról jövő vízfolyás és egyesülve érik el a sziget keleti részét a szárazfölddel összekötő hidat. Az északról érkező víz a térképen a semmiből ered, ugyanakkor északabbra Füredtől is indul egy vízfolyás, ami elvész a mocsárban, feltehetően a két víz ugyanaz.

$A$ város ábrázolása mindkét térképen hasonló. A mai Fő utca, az Ady endre utca és a Vár utca adja a város kelet-nyugati tengelyét. Ehhez két északi irányú út csatlakozik a mai Berzsenyi utca és a mai Zárda utca helyén. Így két fő kereszteződés, két fontos tér látszik a mai Plázánál és a mai Kossuth térnél. Mindkét térképen két út, a Teleki és Irányi utca elődei vezetnek a Giliczénél lévő átjáróhoz, ami a mai gyalogos felüljáró környékén volt. A településről kelet felé kimenő út, a Kisgáti vízfolyás déli részén lévő hídon megy át, majd délkeltre fordulva egy újabb hídon kel át a Kaposon és ment Szentjakab felé. Az utóbbi lehet a Keszi híd utóda. Az úthálózat a középkori viszonyokra is fényt vet, bár a környező falvak jó része eddigre elpusztult. Mindenképpen figyelemre méltó Kaposvár kétközpontú, két főteres szerkezete.

A 2. katonai felmérés térképén a már szabályozott Kapos a vártól délre folyik ${ }^{23}$ (3. ábra). A berek még nagyon kiterjedt, de már csökkent a vizes terület nagysága. A Kaposon a vártól délre van egy híd, a mai vasúti és közúti átjáró előde, ahová a Vár utca vezet. A palotaszárny ezen a térképen valamiért nincs ábrázolva. Az egykori sziget körvonala még látszik, hiszen

22 https://mapire.eu/hu/map/firstsurvey-hungary/?layers=147\&bbox $=1976720.3031202226 \% 2$ C $5837108.072498875 \% 2 \mathrm{C} 1983164.9$ $000675164 \% 2 C 5839018.9982060045$

$23 \mathrm{https}: / / \mathrm{map}$ ire.eu/hu/map/secondsurvey-hungary/?layers=5\&bbo $\mathrm{x}=1977781.5780182313 \% 2 \mathrm{C} 5836817.697715106 \% 2 \mathrm{C} 1981003$. $8764918782 \% 2 \mathrm{C} 5837773.16056867$ 


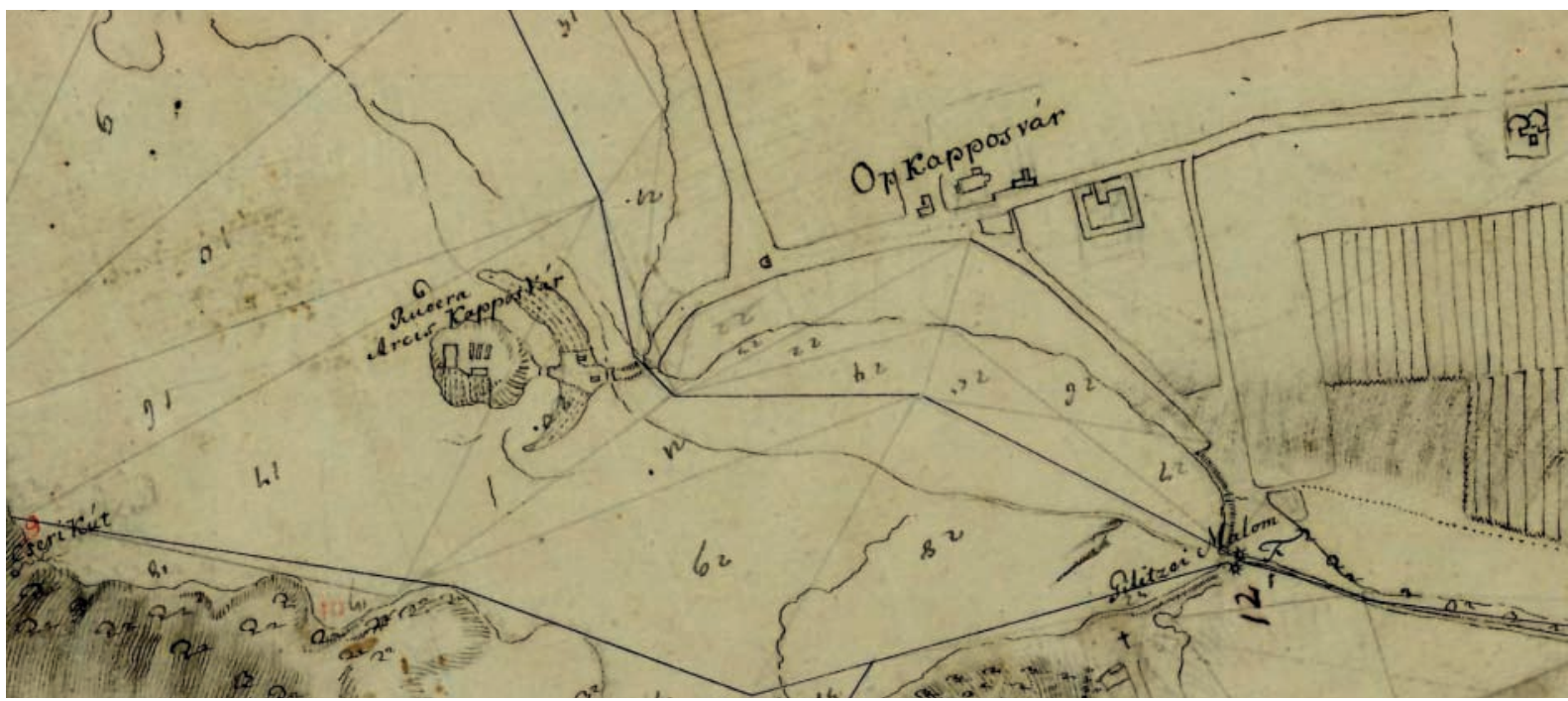

1. ábra. 1778-as vízrajzi térkép (forrás: Hungaricana.hu).

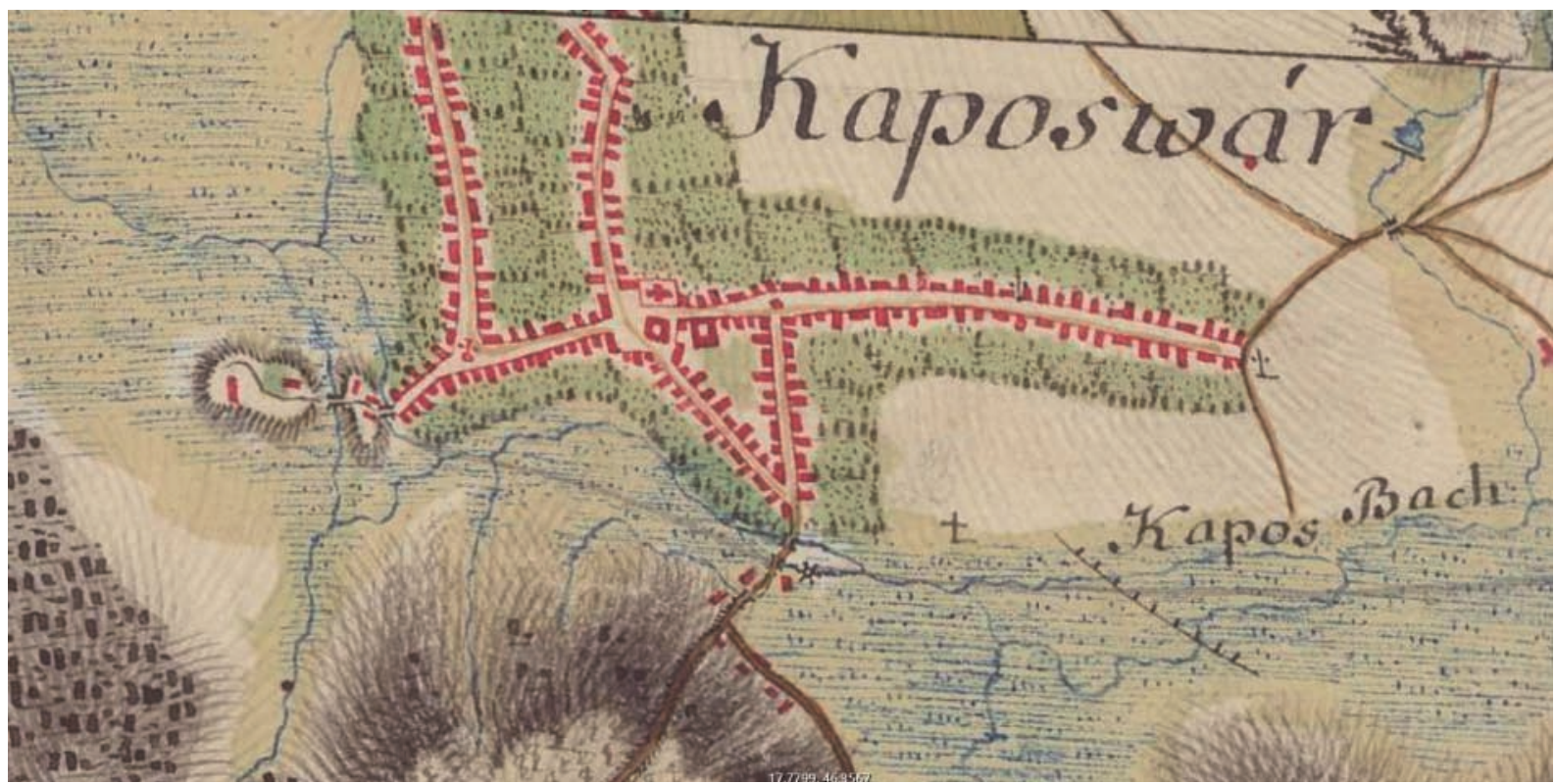

2. ábra. Az 1. katonai felmérés térképe (forrás: Hungaricana.hu).

az egykori víz alatti területek alacsonyabbak. A domb északnyugat részén egy beugrás van. Az úthálózat hasonló az előzőhöz.

Hasonló, de jóval részletesebb képet mutat egy 1865ös kataszteri térkép ${ }^{24}$ (4. ábra). A helyrajzi határok igazodnak a korábbi földrajzi helyzethez. Míg az egykori vár területe és az egykori sziget az Eszterházy család birtokává vált, ide kapcsolható a 1082. (és pl. 1080, 1081, 1078, 1077, 1084.) helyrajzi-számú terület. Az egykor víz alatt lévő terület a folyószabályozás után külön helyrajzi szám alá kerülhetett, ilyen az 1083. számmal jelzett telek. Az 1082 és 1083. közötti határ

$24 \mathrm{https}: / / \mathrm{mapire} . \mathrm{eu} / \mathrm{hu} / \mathrm{map} /$ cadastral $/$ ?layers $=3 \% 2 \mathrm{C} 4 \& \mathrm{bbox}=1973$ $729.402631258 \% 2 \mathrm{C} 5835534.51347368 \% 2 \mathrm{C} 1986618.59652584$ $58 \% 2 C 5839356.36488794$ jól kijelöli az egykori sziget és a víz határát. A 2. katonai felmérésen látható északnyugati beugrás itt is megfigyelhető, az egykori vizesárok nyomát őrizheti. Ezen a térképen ábrázolták az egykori nyugati palotaszárnyat valamint több más épület is.

Egy másik, adóhivatali kataszteri térképet is ismerünk a korból. ${ }^{25}$ Ez valamivel részletesebb, hiszen több akkor már megszűnt, más területekkel összevont telket és helyrajzi számot is ábrázol (5. ábra). Az 1082. helyrajzi-számú terület keleti részén egy 846 számú, míg az 1115 terület nyugati részén egy 843. számú megszünt telket jelölnek, amelyek az egykori vizes-

25 https://maps.hungaricana.hu/hu/MOLTerkeptar/17039/?list=eyJx dWVyeSI6ICJrYXBvc3ZcdTAwZTFyIG1lelx1MDE1MXZcdTAwZT Fyb3MgbWFneWFyb3Jzelx1MDBIMWdiYW4ifQ 


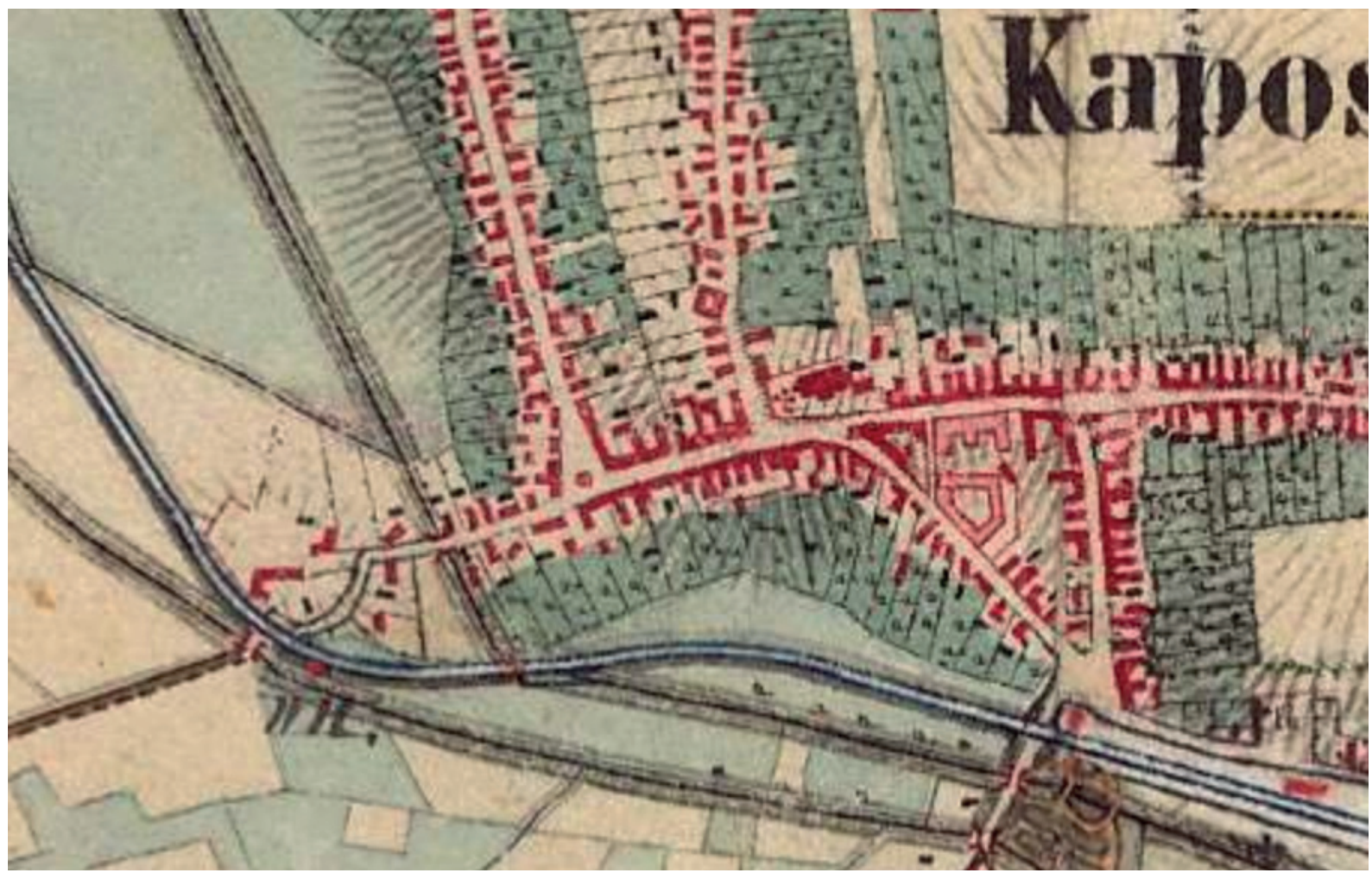

3. ábra. A 2. katonai felmérés térképe (forrás: Hungaricana.hu).

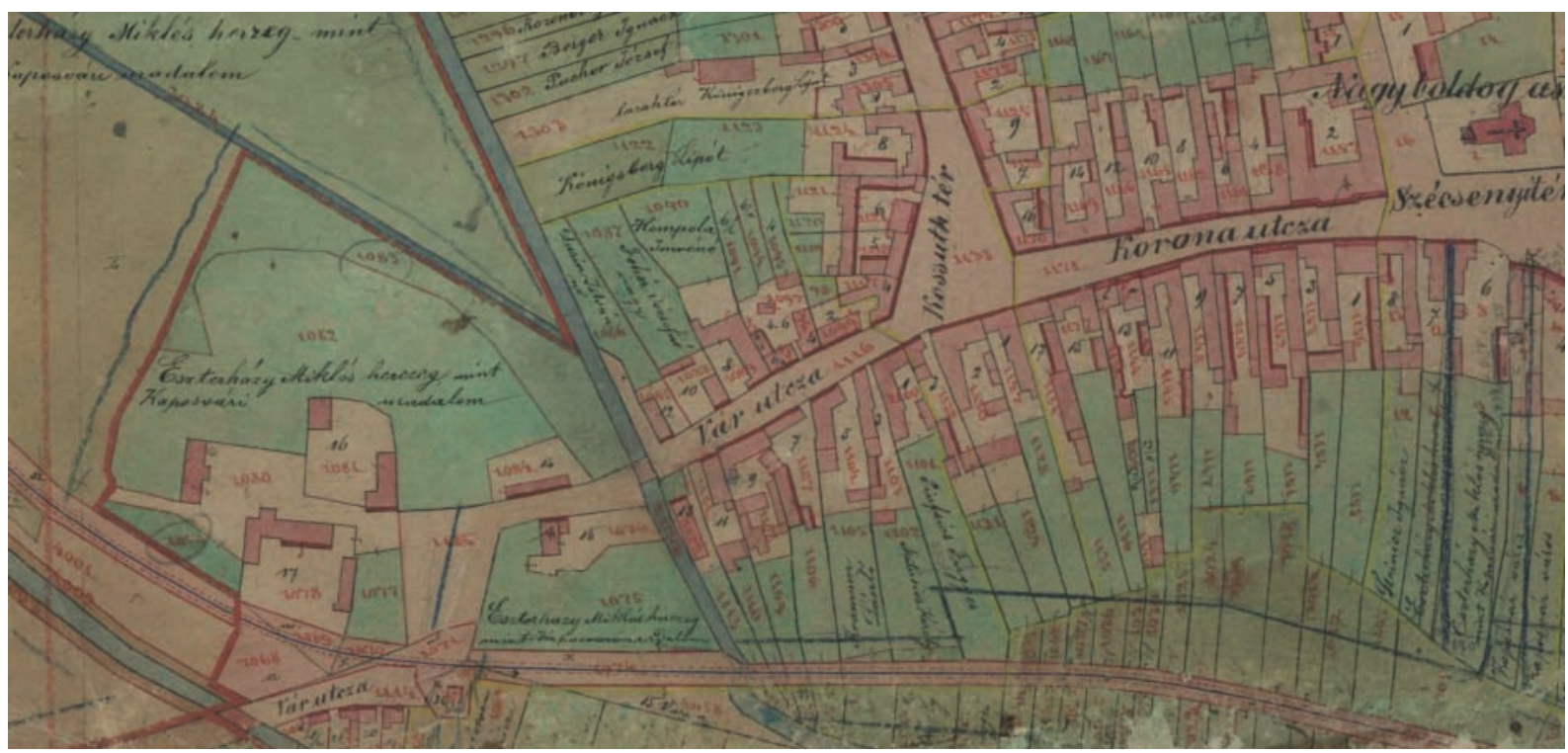

4. ábra. 1865-ös kataszteri térkép (forrás: Hungaricana.hu).

árok észak-déli irányú, keleti szakaszát rajzolhatják ki. A 846 számú terület északnyugati részén lehet a vizesárok kanyarodása, amely a tőle nyugatra lévő, számnélküli területen folytatódik és az 1082. terület beugrásáig tart.

A kataszteri térképen talán a külvárost körbevevő palánkról is információkat szerezhetünk. A külvárost kerítő palánk déli oldalának nyomát örizheti a telkek déli határát jelentő kb. egyenes vonal. A Vár utcától északra a függőlegesen, észak-déli irányban sorakozó telkek és a tőlük északra lévő, vízszintes kiosztott (1122, 1123, 1124 helyrajzi-számú) telkek közötti határ lehet a város egykori északi falának és az itt lévő ároknak a helye. $A$ város keleti határát általában mai Berzsenyi úthoz, néha a mai Kossuth térhez szokták valószínüsíteni, az említett vonalak az előzőig biztosan elérnek. 


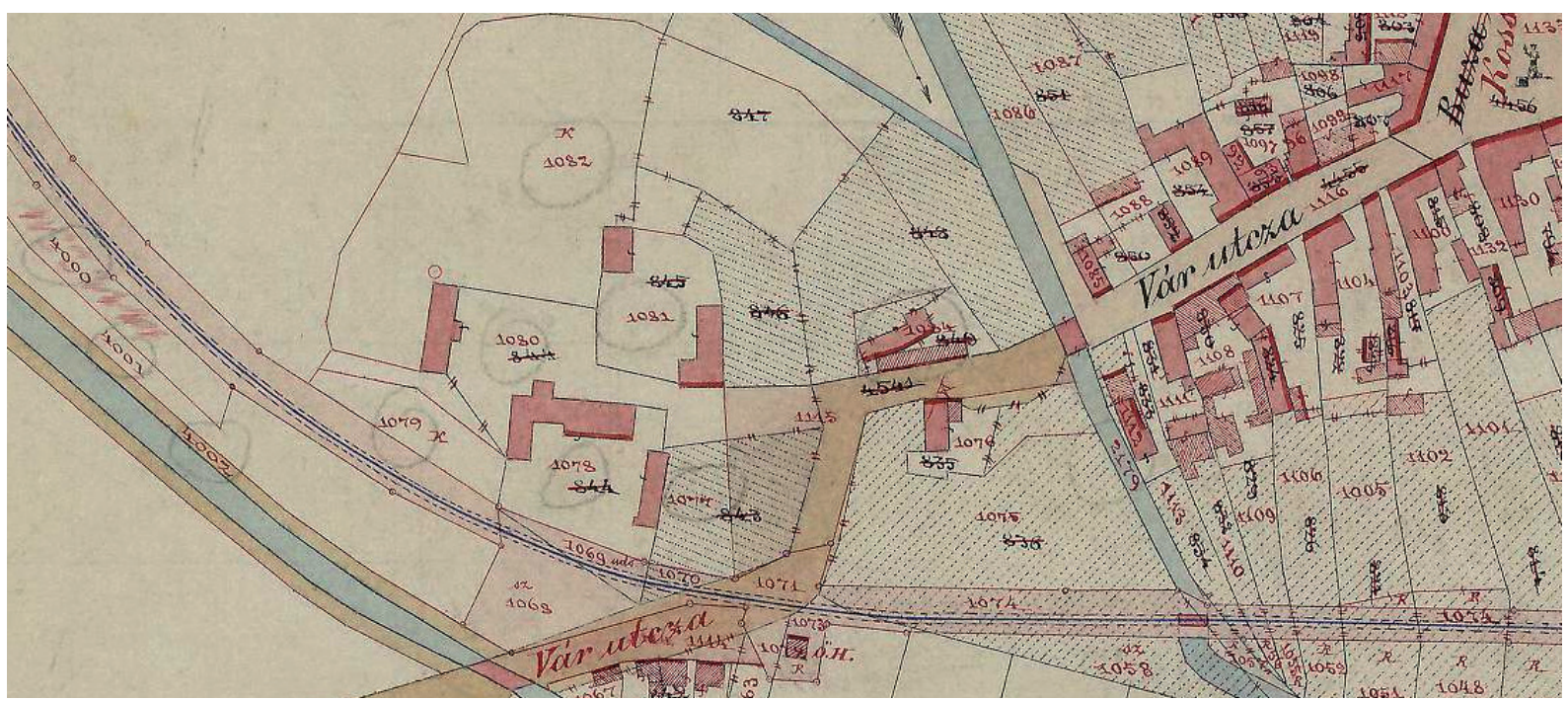

5. ábra. 1865-ös adóhivatali térkép (forrás: Hungaricana.hu).

\section{Közép- és török kori leírások}

Sajnos csak kevés olyan korabeli leírás maradt meg, amelyből a vár formájára is információt szerezhetünk. Az első ilyet Bonfininél találjuk Kaposújvár 1495. ostroma kapcsán:,„Amikor a katonák átkeltek a hármas vizesárkon, nyomban elkeseredett tusába bocsátkoztak, majd az utolsó sáncot is elérve véres közelharcot kezdtek"26

Leírása alapján három árkot kell keresnünk, valamint többsoros középkori palánkfalat. Utóbbi nyomait egyelőre nem találtuk meg. A három árok említése látszólag összecsengene az 1687-es kamarai leírás három árkával, ugyanakkor utóbbinál a külváros árkát is említik. A feltáráson, a téglafalakhoz közel egy árok nyomát találtuk meg, amit a török korban már betöltöttek. Bonfini idején még ez lehetett a szigetet a szárazföldtől elválasztó és a szigetet kettévágó árkok utáni harmadik, legbelső árok.

Dzseláledze Musztafa 1555-ben két árkot, valamint két palánkfalat említett: „A nevezett vár a Kapos nevű víz közepén fekszik, mely egészen körülveszi s minden oldalról nehezen járható hegyek kerítik. Széles árkán belül van a nagy palánk, azon belül az erős párkány és harmincrőfnyi széles árok, tele vízzel. A párkánynak minden oldala hantból, deszkából és gerendákból van építve és bástyákkal ellátva."27

Evlia Cselebi 1664-es leírása szerint: „Ez a vár olyan, mintha Kanizsa várának a fia volna. Kanizsa gyanánt egy nádas, mocsaras, mély völgyben áll, mint négy lábán a béka. A mocsár vize a Kapos folyón az árkon átfolyik s igen nagy víz. Vára nincs oly nagy, mint Kanizsa, hosszúkás, négyszög alakban fekszik. Egész építkezésének az alapján fagerendák vannak, körös-körül tömésfalakkal övezett palánkja. Belső vára azonban nagyon erős és háromszáz deszkazsin-

26 Bonfini 1995. 998-999. V. könyv 10

27 Thury - Kiss 1984. 152 delyes tetejü, kert nélküli, szűk háza van. Szulejmán khán dzsámija, hadiszertára, élelmiszer raktára, keletre nyíló vaskapuja, előtte felvonó hídja és tornya van. Egy tágas síkon a Kapós folyó mocsarai közé épült hosszúkás négyszögű külváros. Palánkafalának szélességét teljes ötven lépésnek találtam. ... minden oldalán nagy bástyák és minden szöglet könyökénél lőrések vannak. Kapui előtt, az árok fölött levő hídjai csigákon járnak. E városban van a Khunkjár dzsámi és más egy-két dzsámi. Van két medreszéje, hat elemi iskolája, két helyen kolostora s mintegy ötven boltja. Három iszlám városrésze van, a többi keresztény. Utcái deszkaburkolatúak, ép úgy, mint Kanizsán, mert süppedékes hely. Vize és levegője nagyon kellemes. Szép arcú és egészséges népe van."28

A leírás szerint a külváros tágas síkon volt, ugyanakkor a Kapos mocsarai között. Tehát egyértelműen nem az egykori szigeten kell keresnünk, hanem keletre a szárazföldön, a mocsaras terület mellett. A 18. századi térképek alapján nemcsak nyugatról határolta víz, de déli oldalán is a Kapos széles ártere húzódott, sőt az észak oldal nyugati sávjában is zsombékos, mocsaras terület volt. A városfalról azt is megtudjuk, hogy erös falakkal, bástyákkal, árokkal és felvonóhidas kapuval bírt. A vár (azaz a neki helyet adó sziget) mocsaras völgyben állt. Cselebi megkülönbözteti az erős belső várat, amelynek vaskapuja felvonó hídja, tornya van.

Az 1687-es kamarai összeírás szerint a várat hármas árokrendszer fogta körül. Az első árkon belül $50 \mathrm{db}$. az ostromban lerombolt, egykor részben katolikus, részben „rác” vallásúak által lakott ház volt. A másik árkon belül, egy hídon és két kapun túl, egy hosszú utcában 56 lakott és 8 elpusztult „török” ház, a harmadik árkon belül, a belső várban 48 lakott és 15 lakatlan török ház volt. ${ }^{29} \mathrm{~A}$ sokat idézett leírásban tehát hármas árokrendszert említenek. Az első a szárazföldön lévő külvároshoz tartozott,

28 Evlia 1908 . 33-34.

29 Először közli Hoss 1948. 213. 16. jegyzet 
amelynek lakossága részben ortodox részben katolikus volt, valószínüleg az utóbbiak is a Balkánról érkeztek. A középső árok a szigetet választotta el a szárazföldtől. Ezen belül volt a muszlim városnegyed. Majd a harmadik árok a belső palánk előtti, a szigetet kettéosztó, a belső várat kerítő középkori eredetű árok volt.

\section{Török kori ábrázolások}

A török kori vár több ábrázolását ismerjük, de sajnos ezek egymásnak is jelentősen ellentmondanak. A várakat ábrázoló metszetek legtöbbször a háború iránt érdeklődő nyugati közönségnek készültek, sokszor nem a hitelességre, hanem az eladhatóságra törekedtek, forrásértékük különböző, többnyire nem tekinthetőek az egykori várak pontos ábrázolásának. ${ }^{30}$

A legismertebb, legtöbb helyen szereplő Giovanni Giacomo de Rossi által készített, a városházán is látható ábrázolásnak valószínüleg nem sok köze van a valósághoz ${ }^{31}$ (6. ábra). Hoss József is mint legismertebb ábrázolást, de nem ezt említette leírásoknak legmegfelelőbbnek. ${ }^{32}$ Zádor Mihály, majd Deák Varga Dénes nagyjából hitelesként fogadta el, Szakály Ferenc „legalább is egyes részleteiben fiktívnek" említette, Tímár Péter alapvetően hiteltelennek tartotta a metszetet. ${ }^{33}$ Magam az utóbbival értek egyet, mivel a rajzon semmit sem látunk a téglavárból, a korabeli leírásokkal sem egyeztethető össze. Ismerünk egy Kalocsa várát ábrázoló szinte ugyanilyen metszetet. Sajnos a metszet sokáig megzavarta a kutatást, a vár rekonstruálásakor is felhasználták, vagy a téglavárral próbálták megfeleltetni vagy a köré rajzolták be, középső vagy külső várfalként.

Hitelesebb lehet az úgynevezett Manone-féle metszet $^{34}$ (7. ábra). Először Hoss József közölte és a „leírásoknak legmegfelelőbbnek" tartotta. ${ }^{35}$ Szakály Ferenc „némileg idealizáltnak” jellemezte, ezzel az általa közölt három ábrázolás közül ez kapta a legkevésbé negatív minősítés. ${ }^{36}$ Deák Varga Dénes alapvetően hitelesnek tartotta, bár megemlítette tájolási problémáit is. ${ }^{37}$ Tímár Péter is ezt az ábrázolást tartotta a leghitelesebbnek, ez alapján próbálta a vár és a város képét rekonstruálni. ${ }^{38}$ Magam is ezt az ábrázolást tartom a leghasználhatóbbnak, hiszen ezen felismerhetőek azok a részletek, amelyek a vár meglévő maradványaiból kikövetkeztethetők. Jól azonosítható a belsővár, azaz a középkori eredetű téglavár trapéz alakú tömbje, a falakon belül álló nagy, négyzet alaprajzú torony és a sarkon álló kerek torony, a téglafalak köré épített palánk. Ugyanakkor teljesen

30 A kérdésröl pl. Basics 2002., Szalai 2001.12-14. Szalai Béla a vár 7 különböző ábrázolását és ezek 4 további változatát említi (Szalai 2001. 34.)

31 Eredeti helye: Rossi 1687. 33. Részletes ismertetése: Szalai 2001. 88. A tanulmányban közölt kép közvetlen forrása Tímár 2016. 113.

32 Hoss 1948. I. tábla 3. kép

33 Zádor 1964. 63., Deák Varga 1993. 36-37, Szakály 1975. 130., Tímár 2016. 114-115.

34 Eredeti helye: Manone 1686. 432-433. Részletes ismertetése: Szalai 2001. 88. A tanulmányban közölt kép közvetlen forrása Tímár 2016. 114.

35 Hoss 1948. I. tábla 1. kép

36 Szakály 1975. 129.

37 Deák Varga 1993. 35-36

38 Tímár 2016.112-114. hitelesnek ezt az ábrázolást sem tekinthetjük, a vár és a természeti környezet ábrázolásában, elrendezésében több nyilvánvaló hibát felfedezhetünk. Mivel nem tünik stilizáltnak, talán valamennyire valósághűnek tarthatjuk a fallal körülvett település ábrázolását is, dzsámiijaival, minaretjeivel, szorosan egymáshoz épített házaival. Magam arra tippelnék, hogy valaki tényleg járhatott a Kaposvári várnál és az ő eredetileg pontos rajzát, vázlatát rajzolhatták át később.

A Johannes Waldmann és Ulrich Kraus által készített metszet ismét erősen különbözik az eddigiektől ${ }^{39}$ (8. ábra). Hoss József közölte, Zádor Mihály alapvetően hitelesként fogadta el, kiemelte, hogy hasonlít a Rossi féle metszetre, viszont a belsővár túlzott magasságát torzításnak tartotta. ${ }^{40}$ Szakály Ferenc nem tartotta hitelesnek az ábrázolást, Deák Varga Dénes viszont nagyjából valósághűként kezelte. ${ }^{41}$ Tímár Péter a város képét nagy vonalakban helyesnek, a várat illendően eltorzítottnak és kevésbé értékelhetőnek tartotta. ${ }^{42}$ Véleményem szerint a metszet kevésbé használható, a belső vár az eltúlzott magasságán kívül más problémákkal is küzd. Ugyanakkor a négyzetes alakú vár és az azt kifli alakban körbevevő városka képe jól megfeleltethető a 18. századi térképeken látható vizesárokkal kettévágott szigetnek. Talán valamilyen információi lehettek a rajzolónak, de az ábrázolás összességében nem hiteles.

A legkevésbé ismert az úgynevezett Panceri-féle metszet ${ }^{43}$ (9. ábra). Tímár Péter rámutatott a Manone metszettel való hasonlóságára, attól kevésbé hitelesnek tartotta. ${ }^{44}$ Ezzel is egyet tudok érteni, talán a két metszet közös előképre megy vissza.

Kaposvár vára szerepel a térség várait ábrázoló, a Kiskomáromi várat középpontba helyező térképen is (10. ábra). A rajz sematikus, ugyanakkor az ábrázolt várak különböznek egymástól, talán annyit érdemes megjegyezni, hogy nem kerek, hanem szögletes olaszbástyákat ábrázol. ${ }^{45}$

Dénes József egy Stockholmban őrzött alaprajzot/ tervrajzot, azonosított Kaposvárt ábrázolásaként ${ }^{46}$ (11. ábra). Az alaprajz felső részen lévő kis Magazin feliratú négyzetet a középkori téglavárnak gondolta, ami bizonyára nincs így, hiszen a vár méretéhez képest a négyzet nagyon kicsi. Figyelemre méltó, hogy a Magazeno felirat előfordul a Manone féle metszet belső vár ábrázolásánál is, a metszetről ugyanakkor teljesen hiányoznak a belső vár ismert elemei. Ha csak a palánkoknak helyt adó sziget ábrázolására koncentrálunk, nagyjából hitelesnek fogadhatjuk el.

39 Eredeti helye Waldtmann-Kraus 1696. III. 356-3557. Részletes ismertetése: Szalai 2001. 88. A tanulmányban közölt kép közvetlen forrása Tímár 2016. 115.

40 Hoss 1948. I. tábla 2. kép, Zádor 1964. 66.

41 Szakály 1975. 131., Deák Varga 1993 37-38.

42 Timár 2016. 115.

43 Eredeti helye Panceri 1687. 416-417. Részletes ismertetése: Szalai 2001. 88. A tanulmányban közölt kép közvetlen forrása Tímár 2016. 116.

44 Tímár 2016. 115-116.

45 https://maps.hungaricana.hu/hu/MOLTerkeptar/8422/ view/?bbox $=1337 \% 2 \mathrm{C}-719 \% 2 \mathrm{C} 2702 \% 2 \mathrm{C}-149$

46 Dénes 2015. A rajzot eredetileg Kisari Balla György közölte (Kisari Balla 1996. 161., 105. tábla) 


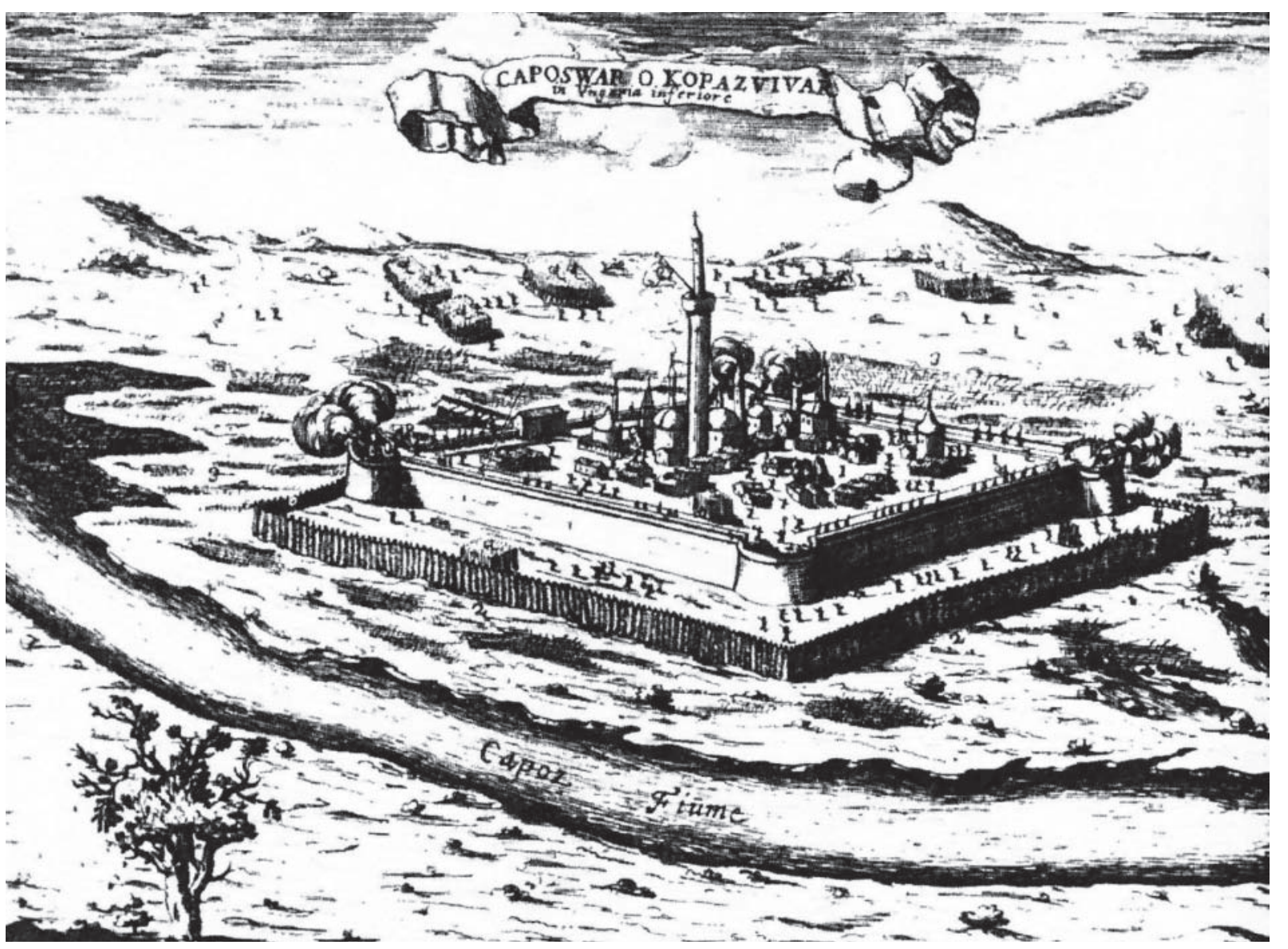

6. ábra. Giovanni Giacomo de Rossi metszete.

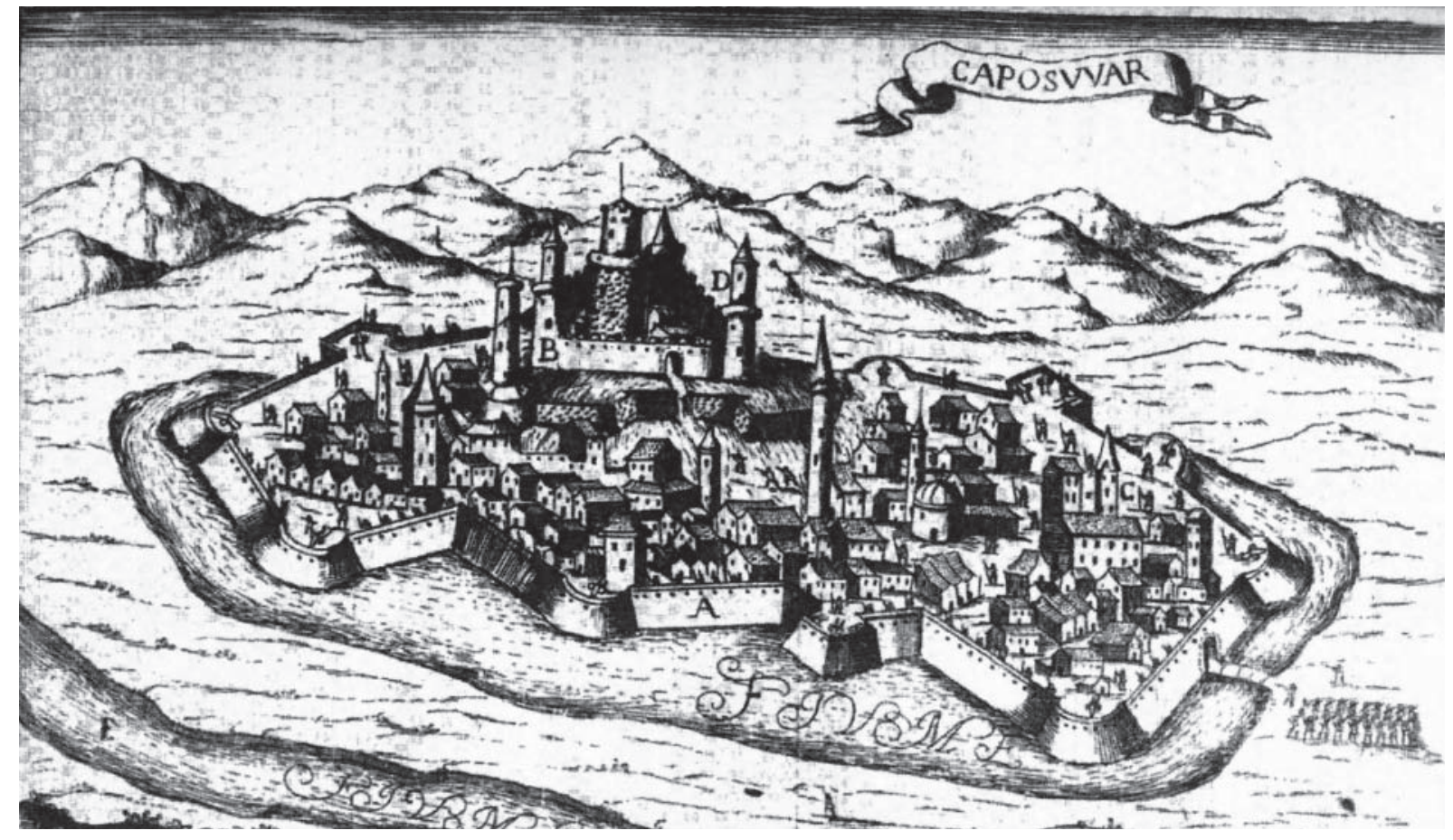

7. ábra. Carlo Manone metszete 


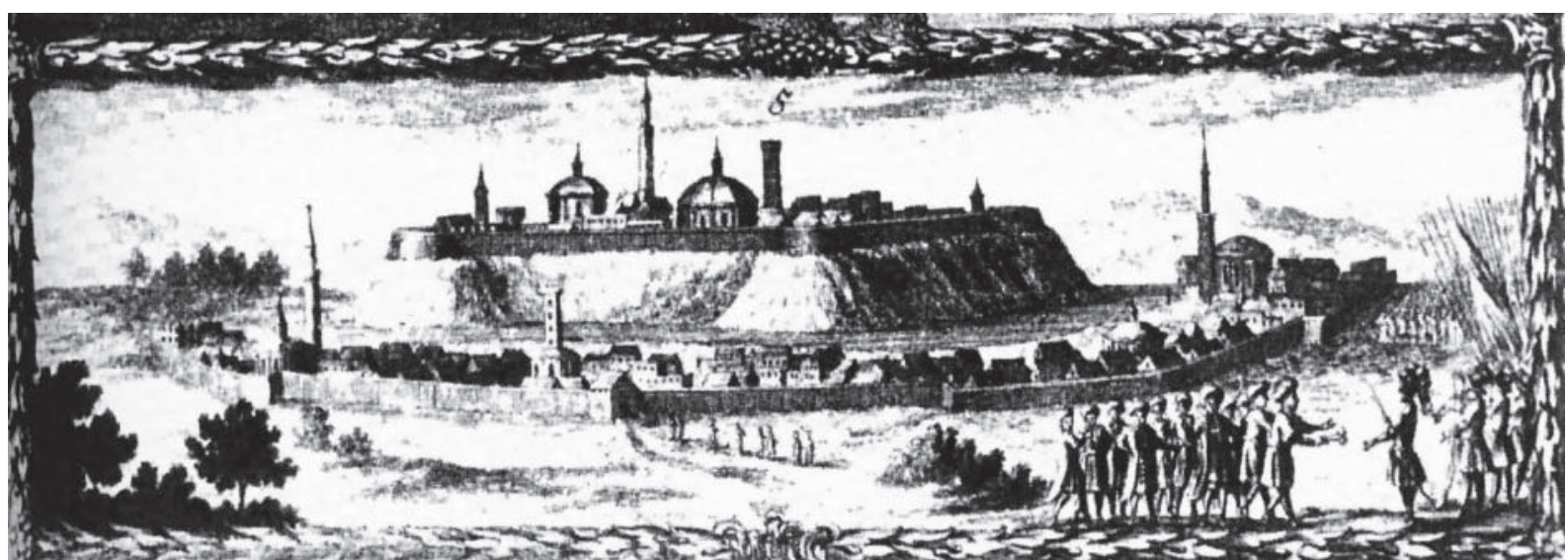

8. ábra. Johannes Joseph Waldtmann és Ulrich Kraus metszete.

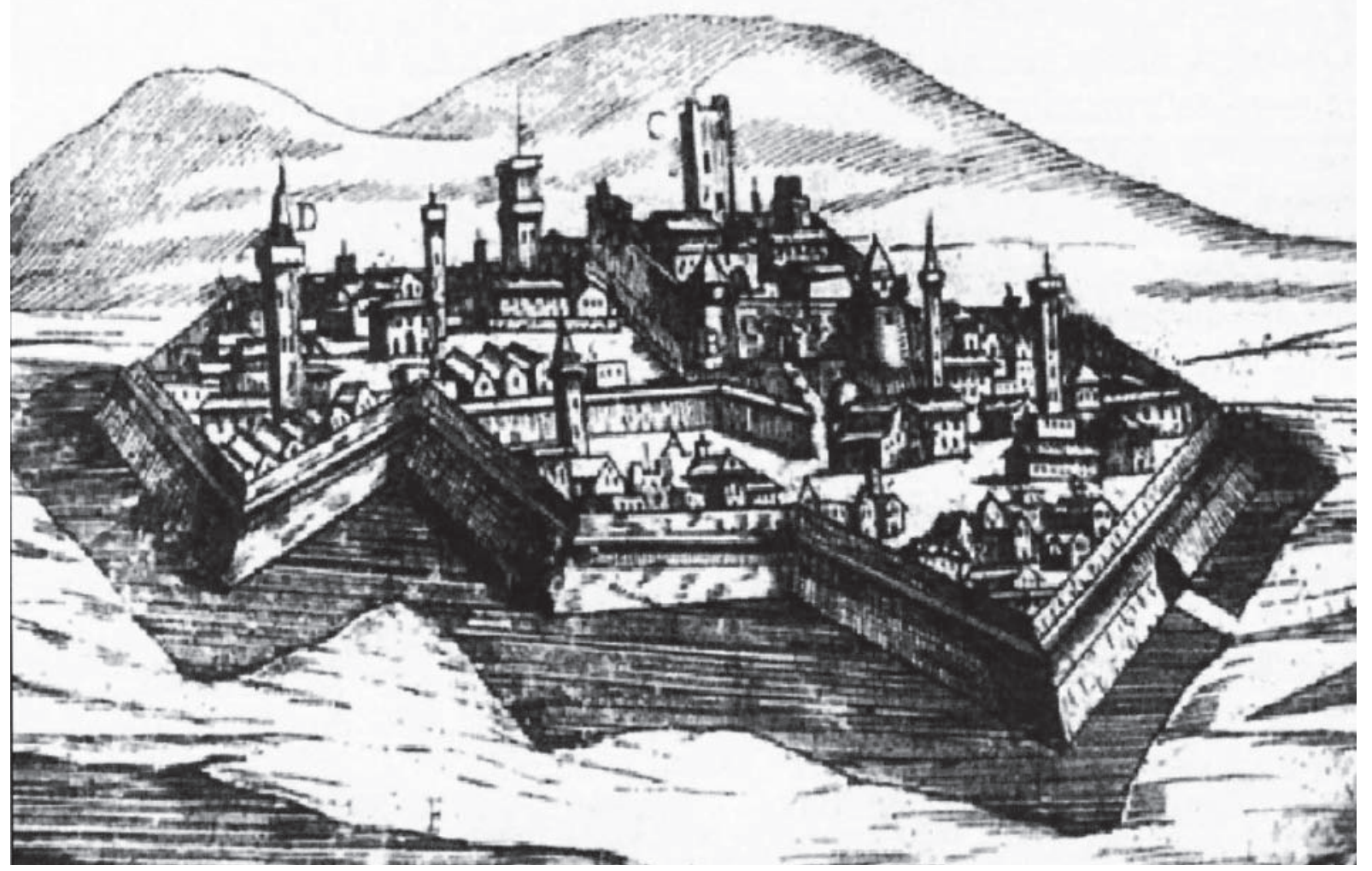

9. ábra. Giovanni Antonio Panceri metszete.

Az egymástól vizesárokkal elválasztott négyszögletes és ívelt, kifli alakú erődített terület elég jól illeszkedik 18. századi térképeken látható ívelt vizesárokkal átvágott szigethez. Az alaprajz és a 18. századi kataszteri térképek ábrázolásai között is jól látható egyezések fedezhetőek fel. Az alaprajz többé-kevésbé ráilleszthető a kataszteri határok által kijelölt területre, sőt a nyugaton lévő beugrás és az adóhivatali térképen jelölt belső határok alapján kirajzolódó vizesárok helye is megfeleltethető neki. A vizesárkot a feltáráson is nagyjából megfelelő helyen találtuk meg. Ugyanakkor a rajzon a palánkfalak közvetlenül a vizesárok szélére vannak rajzolva, míg a feltáráson attól távolabb, a téglafalakhoz közelebb tártuk fel a palánk maradványait. 


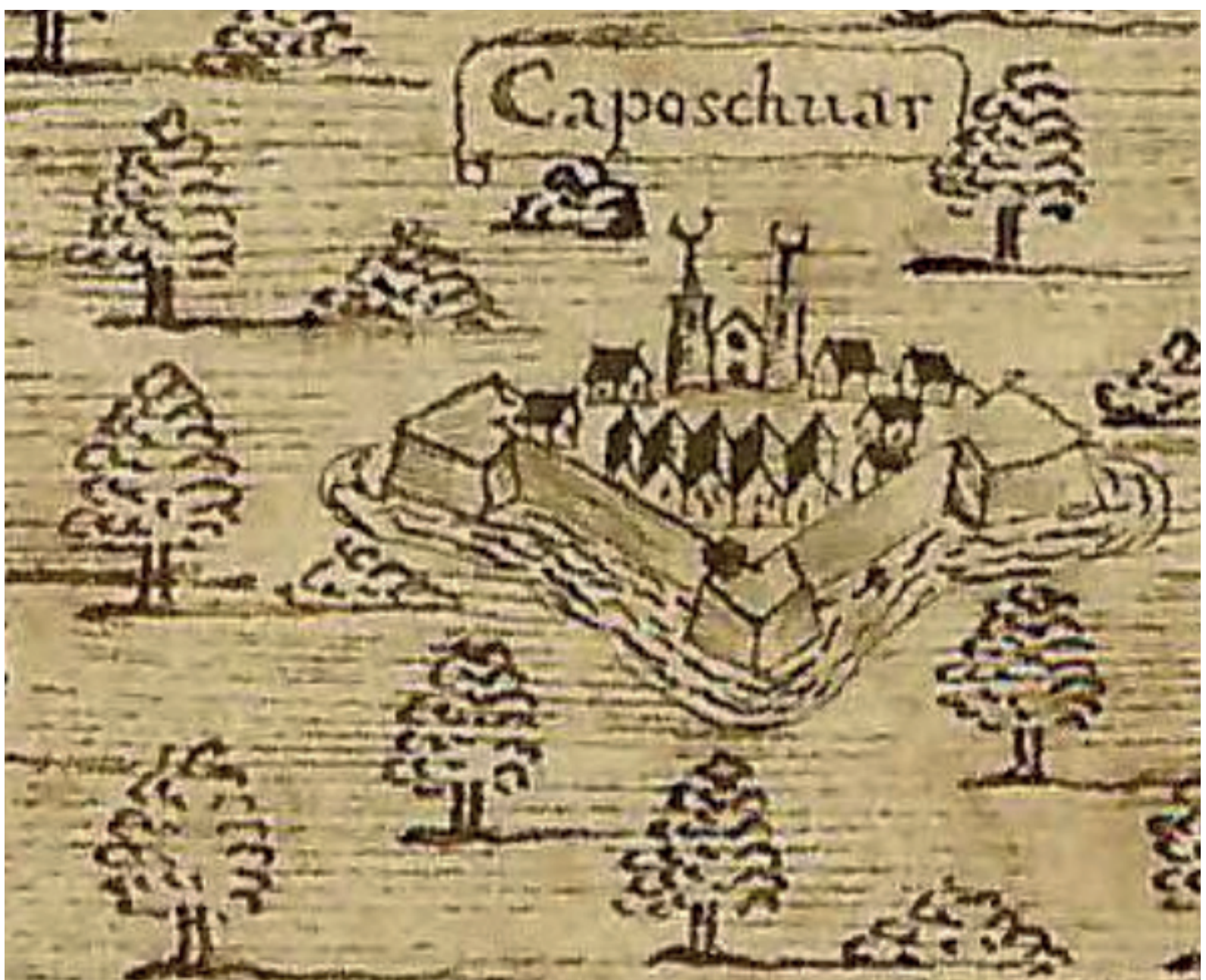

10. ábra. Kaposvár a Dél-dunántúli várakat ábrázoló térképen.

A külváros helyén egy sematikus négyzet van ábrázolva. A rajz a Stockholmi levéltárban őrzött magyar vonatkozású gyűjteményben maradt meg, a rajzokról úgy tartják a 16. században készültek, más térképekről lettek másolva és számos esetben meg nem valósult erődítési terveket is tartalmaznak. ${ }^{47}$ Mivel a sziget körvonala és a vizesárok ábrázolása helyes, míg a palánkoké nem vagy nem teljesen, a rajz eredeti forrása egy 1555 előtti erődítési terv lehetett.

\section{Korábbi régészeti kutatások}

Az 1930-as évektől már csak a várudvaron álló nagy torony és az északkeleti saroktorony 1-1,5 m magas maradványai, valamint a belső várfalak csekély magasságú részletei (a teljes déli szakasz és egy-egy hozzá csatlakozó kisebb szakasz nyugaton és keleten) látszottak.

A várnál az 1930-as években Lux Kálmán és Szőnyi Ottó kutatott, 1931-ben felmérték a még meglévő falszakaszokat, így a Nostra gyárépülete által megsemmisített északnyugati sarkot is. A felmérési rajzon

47 Domokos 1999 a később is látható falakon kívül a nyugati palotaszárnyat is ábrázolták egy osztófallal, valamint a nyugati és déli oldalon a külső fal egy-egy kis szakaszát is berajzolták. 1957-ben Pusztai Rezső végzett feltárást a Nostrától nyugatra készülő épület helyén, ekkor cölöpsor részletét dokumentálta. ${ }^{48} \mathrm{Amennyire} \mathrm{megállapít-}$ ható a cölöpök a külső várfaltól 15-18 méterre, azzal párhuzamosan sorakoztak. 1958-ban egy újabb épület megépítésekor Parádi Nándor végzett kisebb feltárást, ekkor a vár északkeleti tornyától 10 méterre találta meg a palánk maradványait.. ${ }^{49}$

A következő évtizedekben végzett építkezéseken több alkalommal kerültek elő a palánkok maradványai. 1969-ben a mai vasúti átjárótól 10-15 méterre északkeletre és a téglavár délnyugati sarka mellett találtak cölöpöket. Az 1970-es évek elején és 1985-ben a Vár utcában kerültek elő cölöpök. Magyar Kálmán 1985ben a Vár utcában végzett kisebb feltárást, amely során faszerkezet maradványát találta meg, amit palánk, híd, dongaút részeként határozott meg. ${ }^{50}$ 1999-ben

48 Közölte Zádor 1964. 55

49 Magyar 2004. 189.

50 Magyar 1988. 32-33. 


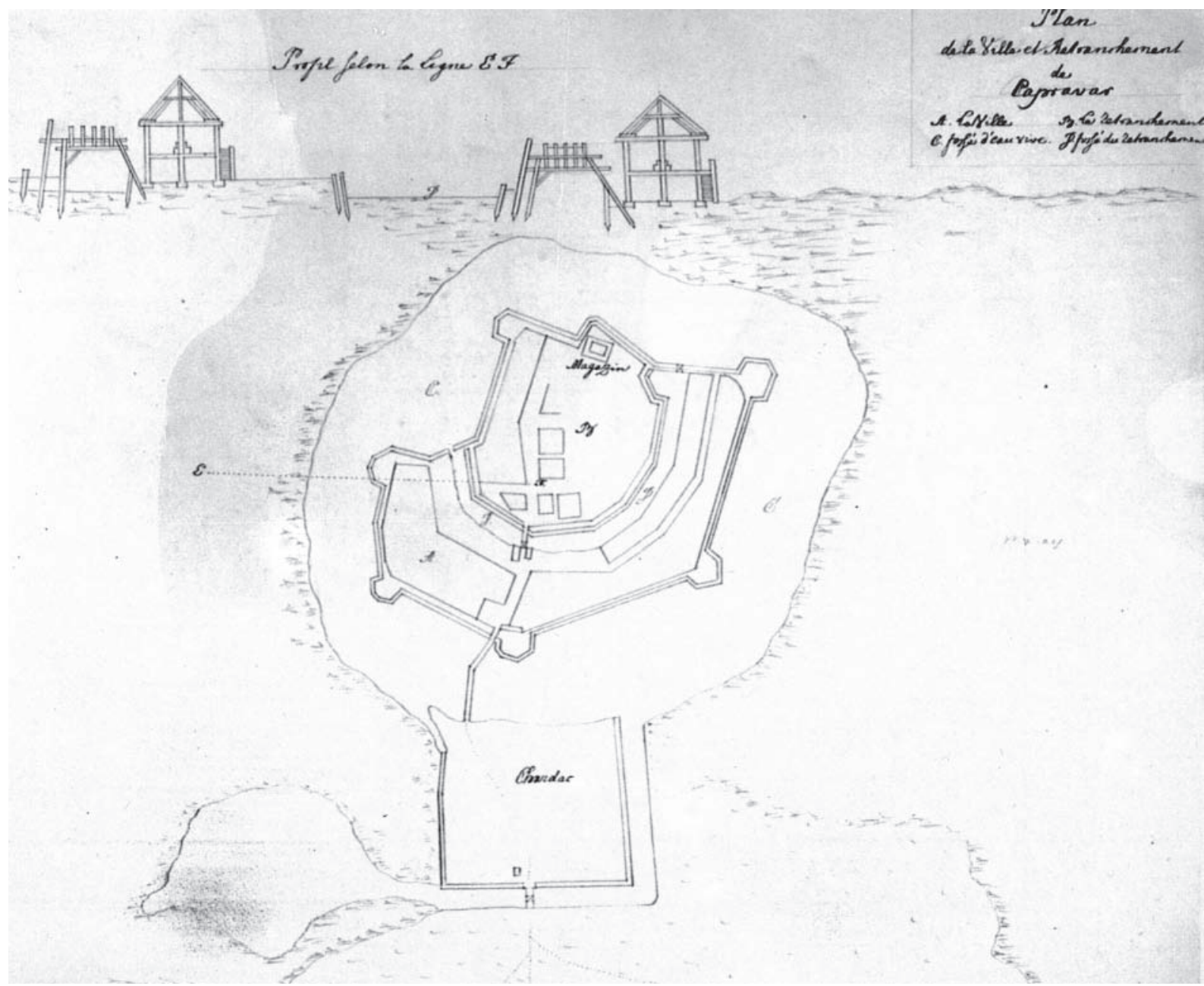

11. ábra. A Stockholmi levéltárban örzött rajz.

Költő László az Ady Endre út 15. szám alatt, 200-275 $\mathrm{cm}$ közötti mélységben vízszintes gerendákat és rőzsekötegeket, a várhoz vezető dorongút maradványait figyelte meg. ${ }^{51}$

2000-ben Magyar Kálmán vezetésével nagyobb felületre kiterjedő ásatást végeztek a belsővár területen. Több kutatószelvényt nyitottak, vizsgálták és dokumentálták a falak alapozását. Újabb falszakaszok is felszínre kerültek, nyugati oldalon feltárták a palotaszárny belső, keleti falának részletét is. A vár délkeleti részén a külső falgyűrű egy részletét is megtalálták. ${ }^{52}$

2006-ban Magyar Kálmán vezetésével a vár utcában, a Plaza közelében folyt feltárást. A talált maradványokat - mocsárra épült cölöp- és deszkavázas építmények, cölöpsorok, fekvő gerendák, kút, gödrök, út részlete - a 17. századi, a kaposvári várhoz tartozó városrész nyomaiként azonosította. ${ }^{53}$ 2007-ben, a mai Corso bevásárlóközpont területén szintén Magyar Kálmán vezette az ásatást, amely során, 1,5-2,5

51 Költő 1999. 215

52 Magyar 2004

53 Magyar 2007. 213-215 $\mathrm{m}$ mélységben településmaradványokat találtak. A gerenda-, deszka-, sövénymaradványok egy részét a várból keleti irányba kivezető híd maradványaként határozta meg. ${ }^{54}$

\section{A vár formájával, kiterjedésével kapcsolatos elkép- zelések}

1948-ban a kaposvári plébánia történetét megíró Hoss József csak viszonylag röviden tért ki a vár formájára, de közölte és röviden minősítette a Manone, Rossi és Waldmann-Kraus metszetet, az elsőt gondolta leghitelesebbnek. ${ }^{55}$

A vár épületeire vonatkozó első bővebb publikációt Zádor Mihály írta. ${ }^{56}$ Közölte az 1931-ben készült felmérést, amelyet sajnos kiigazított, a kissé ívelt déli falat egyenesre, a várat szabályos négyzetre alakította. Erre már azért is szükség lehetett, mert a várat a „Szabályos, négyzet alaprajzú síkalföldi típushoz" so- 
rolta. Közölte Pusztai Rezső ásatási rajzát is. Az első épületének a várudvaron álló lakótornyot gondolta, mellé a 14. századtól palánkfalat, azon belül települést feltételezett. A 15. század közepétől valószínűsítette a várudvart körbevevő téglafal megépítését és a török kor ellőttre a vár „négyrondellás” átépítését. Utóbbit elsősorban a Rossi féle metszet alapján feltételezte.

1975-ben jelent meg a Kaposvár címü tanulmánykötet, a kapcsolódó fejezeteket író Komjáthy Miklós és Szakály Ferenc elsősorban a vár történetével foglalkozott, a vár építéstörténetéről kevesebbet írtak. Egyikőjük sem feltételezett települést a vár mellett a török előtt. Komjáthy Miklós leírása szerint a várat kezdetben még „jelentéktelen mocsárváracska” volt, de az 1440-es évek második felére jelentősége megnőtt, feudális tartományúri központ és török elleni harci álláspont szerepét is betöltötte. A téglafalak körül már a 15. században palánkfalakat is feltételezett. ${ }^{57}$

Magyar Kálmán 1988-ban összefoglalta az eddigi régészeti adatokat. Ismertette a vár lerombolása idején született újságcikkeket és beszámol a különböző építkezések során előkerült palánkfal maradványokról, cölöpökről is. A 14. század közepén toronnyal megerősített, árokkal körbevett, fából épült udvarházszerü épületet tartott valószínűnek, a tornyos kastélyszerü téglavár felépítését a 15. század végére tette. Azt írta a 15. század második felében belső kastély illetőleg külső téglafal és árok készült. A török kori vár kapcsán az 1687-es kamarai leírásra is támaszkodva hármas tagolást (külváros, középső vár, belső vár) feltételezett. $A$ belső téglavárat $30 \times 50$ méter távolságról körbevevő $70 \times 70$ méteres területet bezáró palánksorról írt. Úgy vélte a második árok és palánkfal a Malomároknál, Vár utca nyugati részén volt, a középső várszakasz hosszúsága 180-200 méter lehetett. A külváros kapuját, palánkját, árkát a Széchenyi térre, (azaz a mai Plázához) valószínűsítette. ${ }^{58}$

1993-ban jelent meg Deák Varga Dénes tanulmánya, amelyben föleg a török kori ábrázolásokat és a régi térképeket felhasználva próbálta a vár formáját és kiterjedését meghatározni. Felhasználta az 1778-as vízrajzi és az 1865-ös kataszteri térképet, előbbin a várnak helyet adó szigetet, utóbbin a palotaszárnyat és a vár határait jelző kuntúrokat azonosította. Rámutatott, hogy a török kori ábrázolások közül a Manone metszet a leghitelesebb, de a Rossi és WaldtmannKraus féle metszetet is használta a vár formájának, kiterjedésének rekonstruálása során. A maradványok és a Manone metszet alapján megrajzoltja a középkori vár képet. $A$ várat ő is három részre osztotta (belső és külső várra, valamint erődített városra). A Rossi metszet alapján rekonstruálta a külső várat, 150×150 méter hosszú falakat és kerek tornyokat feltételezett, határát a Malom árok környékére tette.

2004-ben Magyar Kálmán beszámolót írt az általa vezetett 2000. évi feltárás eredményeiről és a vár építéstörténetét is felvázolta. A 12-13. században majorságot feltételezett a területen. Azt gondolta a 13 században felépült a torony, majd a 14. század közepére egy

57 Komjáthy 1975. 77., 81.

58 Magyar 1988. 15-16., 33-34 belső tornyos kastély, amit a 15. században kívül sokszögű tornyokkal bővítettek, majd a 15-16. században megépítették a félköríves rondellát. A török korra tette a keleti és déli szárny külső falait és a vár bővítését keleti irányban egy 4 m széles szárnnyal. Úgy gondolta ehhez a szárnyhoz csatlakozott az eredetileg 11,5-15 m széles várárok, a török korban itt volt a palánk, illetőleg a gerendára fektetett deszkaátjáró, azaz híd, amely keleti végénél egy újabb fal vezetett a középső vár irányába. A közölt térképen a téglavár köré, attól 25-50 méterre egy kissé trapezoid palánk van berajzolva sarkain kerek tornyokkal. Az elképzelés talán a Rossi féle metszeten alapulhat. A külső vár nem látszódik a rajzon, Magyar Kálmán szerint területe egészen a régi Széchenyi térig, valamint ellenkező irányban egészen a Kaposon túli területre is kiterjedhetett. ${ }^{59}$

2005-ben jelent meg Magyar Kálmán és Nováki Gyula könyve Somogy megye várairól, amiben Kaposvár leírása Magyar Kálmán ásatására támaszkodik. Nagyjából a 2004-es cikk megállapításait ismétlik meg, de a torony építési idejét a 14. század első felére valószínűsítették.

Tímár Péter 2016-ban jelentette meg a Szerdahelyi Dersfi családról szóló könyvét, a mü terjedelmes része a Kaposvári várral foglalkozik. A könyv sok szempontból mérföldkőnek számít Kaposvár középkori történetének kutatásában. Szerzője terjedelmes leírást adott a vár és a környező települések történetéröl és a vár formáját, kiterjedését is próbálta rekonstruálni. A vár építési periódusainak meghatározásában föleg a régészeti irodalomra tudott támaszkodni, ez alapján a torony építését a 14. század első felére, a kerítőfalét a 14. század második felére keltezte. Hangsúlyozta, hogy az északkeleti torony nem teljesen kerek és kétségbe vonta a korábbi szögletes tornyok létét is. Rámutatott a Zádor Mihály által közölt alaprajz pontatlanságára is. Felhívta a figyelmet Bonfini leírására, ahol már három árkot és sáncot említettek, ez alapján a palánk elkészültét a 15 . századra tette. Az előkerült cölöpmaradványok alapján igyekezett rekonstruálni a belső palánkfalat. Felvetette, hogy a szigetet átvágó vizesárok a vár legkorábbi időszakában elkészülhetett. Tímár Péter egyértelműen állást foglalt a Rossi metszett hiteltelensége mellett, a közölt négy ábrázolás közül a Manone metszetett tartotta hitelesebbnek a várat jelentős részben ez alapján rekonstruálta. A téglavárat viszonylag közelről kerítő palánkot és árkot feltételezett, míg a második árkot és palánkot a mai Malomárokhoz tette. A harmadik árkot a külvárost kerítő árokkal azonosította, keleti végét a Kossuth térhez, a mai székesegyházon túlra tette, a nagy szintkülönbség miatt szárazároknak tartotta. Véleménye szerint a vár semelyik része nem nyúlt át délre a Kaposon. ${ }^{60}$ Tímár Péter Omak települést a mai Kaposvár központjába, egykori föterét a Kossuth térre, míg templomát a mai székesegyház helyére valószínűsítette, úgy gondolta a külső városfal a templomot és a teret is kerítette. A Manone féle metszeten a város keleti részén dzsáminként jelölt templomszerü épületet Omak egykori temp-

59 Magyar 2004. 191-193

60 Timár 2016. 117-126. 
lomának gondolta. ${ }^{61}$

\section{Röviden a 2019. évi feltárásról}

2019 tavaszán, a már hosszú ideje üresen álló gyárépületek maradványinak eltüntetésére és a terület rehabilitációjára, parkosítására benyújtott pályázathoz kapcsolódva nyílt módunk újabb ásatásra. ${ }^{62} \mathrm{~A}$ RipplRónai Múzeum munkatársai által vezetett régészeti feltárás költségét Kaposvár Megyei Jogú Város önkormányzata bocsátotta rendelkezésünkre.

A munka célja elsősorban az volt, hogy a még rejtőző falszakaszokat megtaláljuk. Fontos volt, hogy a későbbi tereprendezési munkákkal ne sértsék ezeket és hogy esetleg később bemutathatók legyenek. A munkát márciusban és áprilisban végeztük. ${ }^{63} \mathrm{Az}$ első héten a meglévő falszakaszokat szabadítottuk ki a rajtuk lévő földtől és törmeléktől, amelyek nagyobb része a bontáskor került rájuk. Egy néhány évvel ezelőtti rombolás után, még a gyárépületek bontása előtt a déli falszakaszokat lefóliázták és földdel beterítették. Ezt a gépek által néhol keményre járt földréteget is eltávolítottuk. A meglévő falakat követve próbáltunk újabb falszakaszokat találni. A feltárás végére az ismert falszakaszok nagyjából megduplázódtak, még fontosabb, hogy már a vár építésének periódusait is pontosabban el tudjuk különíteni.

A várudvart körülvevő falak eddigi maradványai a nyugati és keleti oldalakon jelentősen meghosszabbodtak, északkeleten is feltárásra került egy pár méteres szakasz. A külső falgyürünek csak kisebb szakaszai voltak ismertek, de a feltárásig ezek sem nem látszottak ki a földből. Most a keleti oldalon szinte teljesen feltártuk a fal maradványait, a déli oldalon is csak a betonozott parkoló alatt lévő szakasza nem került kibontásra. Nyugaton már a 18. században kiszedték az alapozásból a téglákat, így itt csak az alapozási árok volt követhető. A palotaszárny keleti fala is meghosszabbodott észak felé. Sajnos a megtalált falszakaszokból csak az alapozás és a felette lévő néhány téglasor maradt meg. A falak közé ásott szelvényeinkkel a járószinteket, padlókat kerestük, kibontottuk a szelvénybe eső gödröket, kemencéket, egyéb objektumokat. A falak mellett leásva dokumentáltuk azok alapozását. Feltártuk a téglavárat körbevevő palánk és a középkori vizesárok egy szakaszát is (12. és 13. ábra).

Megállapítottuk, hogy a vár északnyugati része, a Nostra gyárépület alápincézése miatt teljesen megsemmisült. A várat máshol is nagy pusztítás érte, nagy területeken a talajvízig eltüntették az újkori építkezések a korábbi rétegeket és szinte mindenhol újkori közművek, vezetékek, betonaknák, modern épületalapok nehezítették a feltárást. Bár a várudvar lebetonozott részét feltörték, általában ez alatt is kézzel áshatatlan rétegeket,

61 Tímár 2016. 141-158

62 Molnár 2019., Molnár 2020.

63 A vár feltárásán a Rippl-Rónai Múzeum dolgozói közül, Molnár István és Harag Mátyás régészek, Stunya Péter, Nyári Zsolt, Balla Krisztián, Cserép Tamás, Papp Zoltán technikusok, rajzolók vettek részt. Ezúttal is köszönjük Szabados Ákos, Újj Kíra régészhallgatók valamint Kovács Gábor, Séta Attila, Szép László önkéntes munkáját és a Pazirik Kft segítségét. betonkeményre járt kavicsréteget, újabb betonsávokat találtunk, így a felső részeket géppel kellett eltávolítanunk.

2020-ban újra lehetőségünk nyílt egy rövidebb kutatásra. A feltárás költségét ismét Kaposvár Megyei Jogú Város önkormányzata bocsájtotta rendelkezésünkre. Első lépésben feltártuk a betonozott parkoló alatt lévő várfalakat, de elsősorban a belső palánk elhelyezkedését kutattuk. Kutatószelvények nyitásával kerestünk olyan területeket, ahol az újkori építkezések kevesebb rombolást végezték és így még feltárhatóak voltak a palánk maradványai.

A lelőhelyen nagy mennyiségü középkori és török kori lelet került felszínre. A háborús eseményekre kő és fém ágyúgolyók, gránátok, puskagolyók, számszeríjnyílhegy, fokos, karpáncél darabja, sarkantyúk, lószerszámdíszek, patkók emlékeztetnek. Gyertyatartót, köves gyürüt, üvegkarpereceket, üveggombot, plombákat, érmeket, rézedények darabjait, vereteket is találtunk. A kerámia anyagban a kályhaszemek, korsók, fazekak, kancsók, fedők, tálak mellett kínai porcelán is előfordul.

\section{A vár földrajzi környezete}

A vár középkori és török kori földrajzi környezete jelentősen különbözött a maitól. A korabeli leírások egyhangúan vízzel körbevett, a mocsárból kiemelkedő szigeten álló várról tudósítanak, arra is van adatunk, hogy a külváros a berekkel szomszédos síkságon volt.

Kaposvár nevü település a középkorban még nem létezett. A várhoz közeli falvak közül az északkeletre, a mai Kaposvár belterületén fekvő Omak és a nyugatra fekvő Kecel érdemel elsősorban említést. ${ }^{64}$ Mindkét helyen átjáró és vámhely volt a folyón. A terület a Rupoly központú nagybirtok északnyugati részén helyezkedett el. Fontos utak találkozásánál feküdt, amelyek itt lépték át a Kapos folyót. Omak pontos helyét, kiterjedését nem ismerjük. Tímár Péter templomát és főterét a mai székesegyházhoz valószínűsítette ${ }^{65}$, amit régészeti feltárás hiányában egyelöre sem megerősíteni sem megcáfolni nem lehet. A 18. századi térképeken látszó úthálózat igazolni látszik ezt, hiszen a fötér ekkor egy fontos útkereszteződésben volt, kérdéses mennyire feleltethető ez meg a középkori viszonyoknak. A belvárosban többfelé talált középkori kerámiatöredékek mindenesetre Omak nyomai lehetnek.

A széles árterü, kanyarodó Kapos folyó és belé futó patakok találkozásánál mocsaras, zsombékos terület alakult ki. Ebből szigetszerüen emelkedett ki egy eredetileg szabálytalan ovális alakú domb. A 2019-ben végzett feltáráson a sziget eredeti dombos felszínét a mai felszíntől 40-80 centiméterrel mélyebben találtuk meg. A nagy torony az északkeleti-délnyugati irányú dombháton volt. A vízszintet a török korban gátakkal szabályozták, a kibontott objektumok alapján a talajvíz szintje a mainál valamivel alacsonyabban lehetett. A 18. században a mocsár vízszintje a korábbinál fentebb kerülhetett, a 18. század végi térképeken ezért látszik szélesnek a vizesárok, és kisebbnek a sziget.

64 A Kaposvár környéki falvakról Tímár 2016.

65 Tímár 2016. 141-158. 

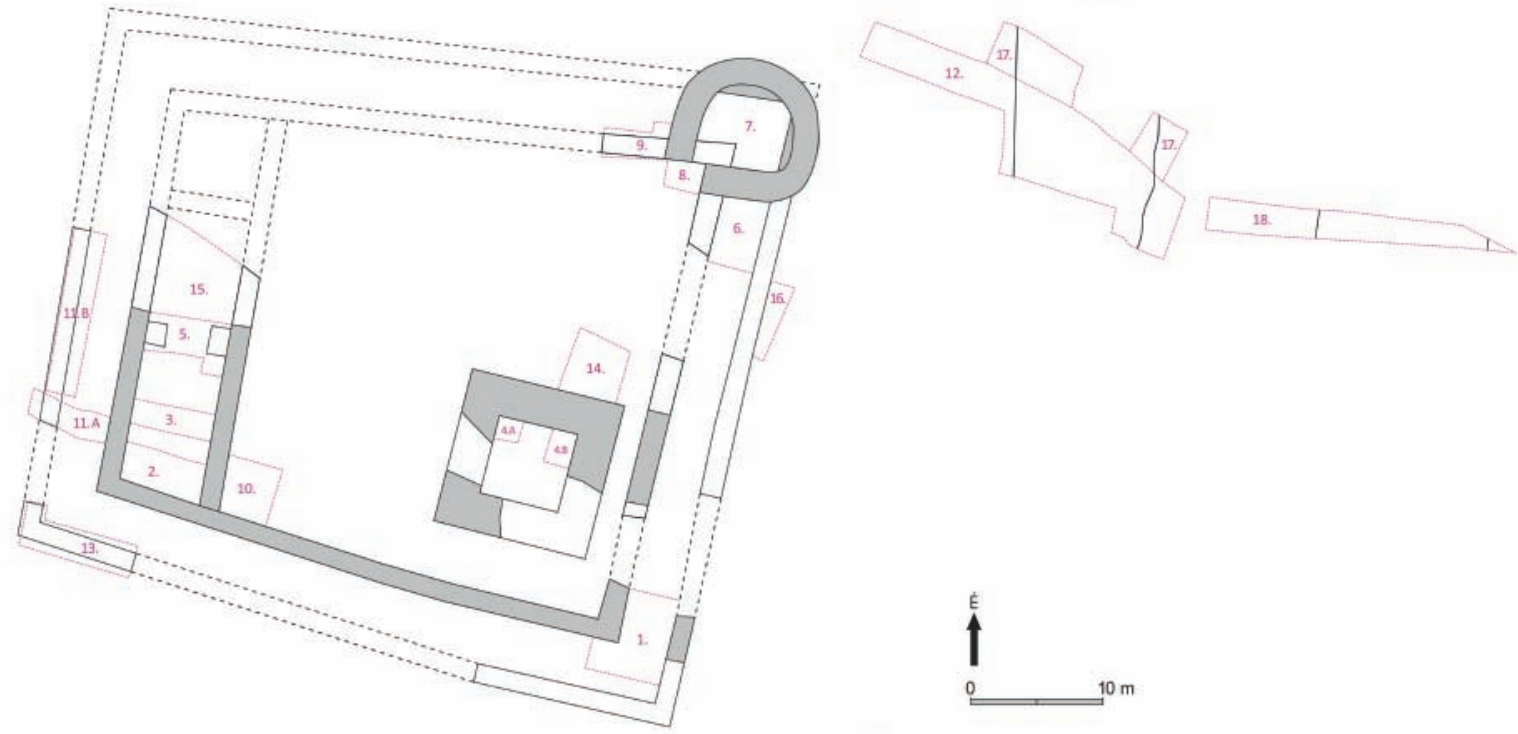

12. ábra. A 2019-ben végzett feltárás szelvényeinek helye. Sötéttel a korábban is ismert, világossal a 2019-ben megtalált falszakaszok

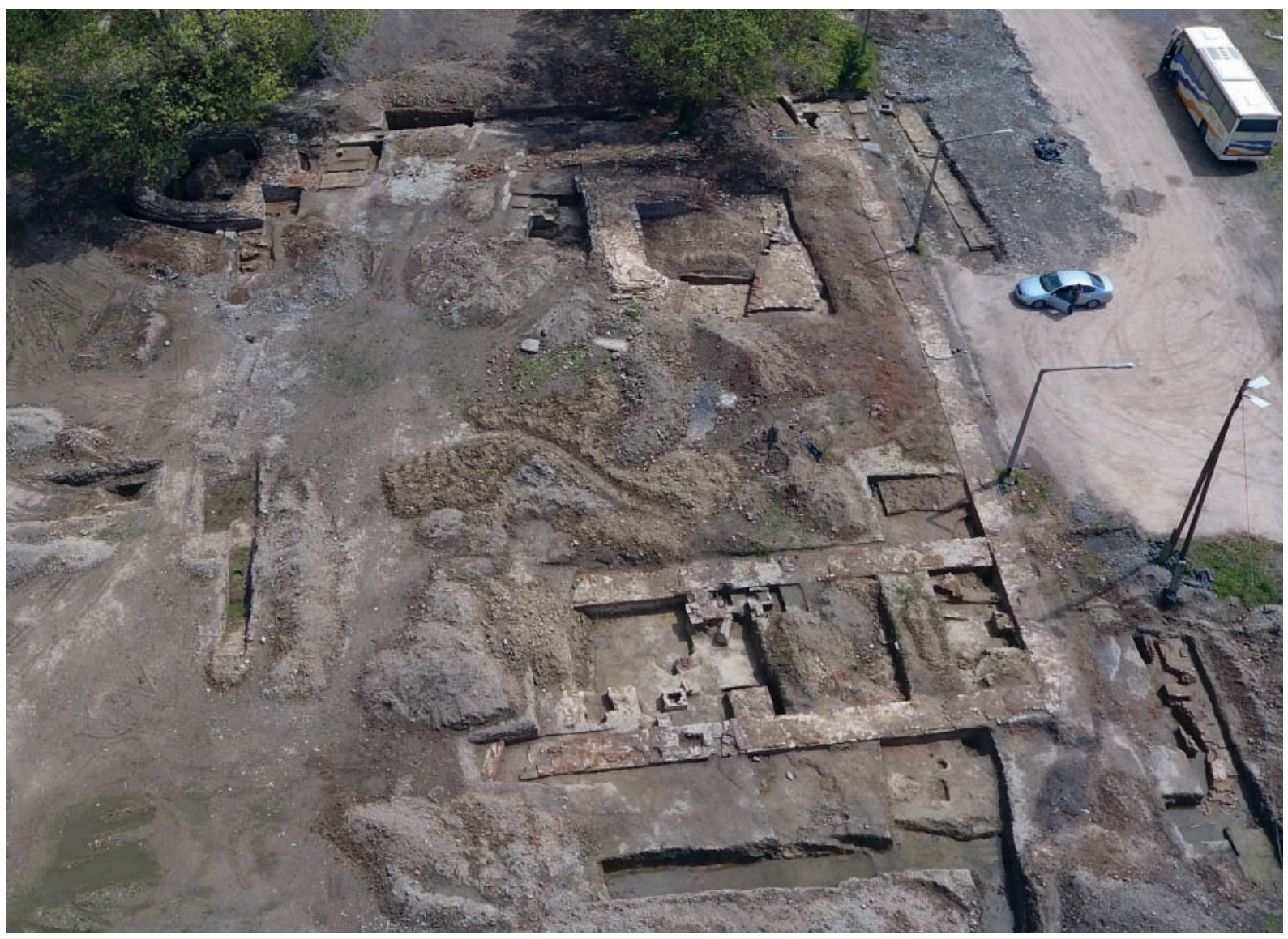

13. ábra. Drónfelvétel a feltárási területről (készítette: Borzavári Balázs) 


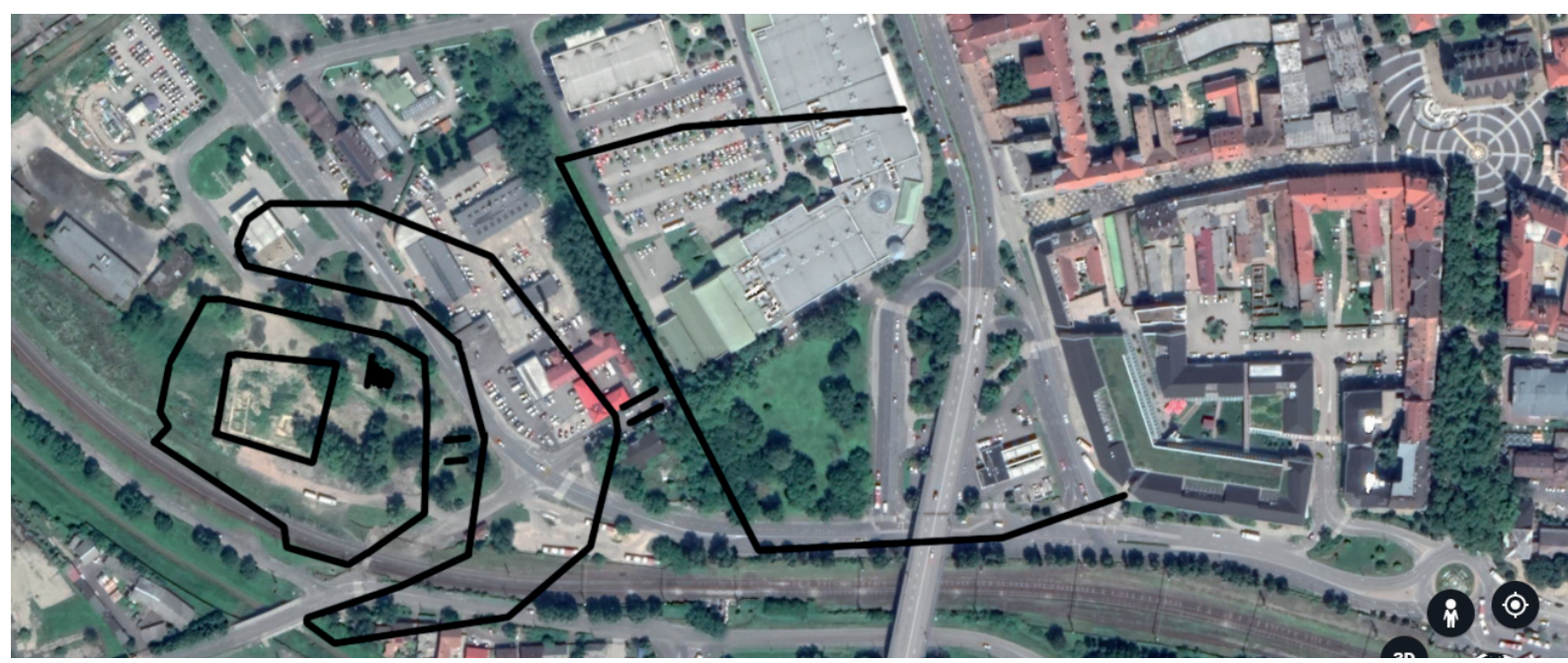

14. ábra. A várnak helyet adó sziget és az azt kettéosztó vizesárok, valamint a török kori külváros újkori térképek alapján feltételezhető határai a google müholdképére rajzolva. A nyugatabbi szigetdarabon ábrázolva van a középkori vár körvonala, a besatírozott terület a palánkfal megtalált szakaszát jelzi.

A Kapos szabályozása csökkentette le a vízszintet a maira és alakította ki a mai környezetet.

A terület kiválóan alkalmas volt várépítésre. A környező mocsaras terület miatt jól védhető volt, ugyanakkor fontos utakhoz közel feküdt, ellenőrizhetőek, szemmel tarthatóak voltak a közeli átjárók Omaknál, Kecelnél. Omakon a birtokos család egyik udvarháza is állhatott.

A sziget eredeti kiterjedése a régi térképek alapján valamennyire még rekonstruálható. Keleten a mai Vásártéri út keleti oldalára is áthúzódott, de a mai Malomárok vonaláig nem ért el, a folyó szabályozásáig ott még szélesebb víz volt. Északon nagyjából a Nostra egykori telkénél volt a határa, a mostani benzinkút területének a nagyobb részét is magában foglalta. Délnyugaton a mai vasútig érhetett, délkeleten kissé túllóghatott azon (14. ábra).

\section{A vár korai épületei}

A későbbi vár területén már az őskorban megtelepültek, a mészbetétes kultúra egykori telepére kerámiatöredékek és a toronynál megtalált nagyobb objektum utalnak. A 2000-ben végzett feltáráson Magyar Kálmán megállapította, hogy a 12-13. században is lakták a dombot. ${ }^{66} \mathrm{Ha}$ a várnak esetleg volt is valamiIyen előzménye, pl. egy fából épült toronyvár, ennek nyomát nem találtuk meg.

A vár legkorábbi épülete valószínűleg a várudvar délkeleti részén álló, nagyméretü, 11,8×11,8 m-es, négyzet alaprajzú torony ${ }^{67}$ (15., 16. és 17 . ábra). A torony téglából épült, falaiból 15 sor maradt meg, alatta 2,85

66 2019-ben a torony belső oldalán egy kisméretű, 15 cm-es cölöphelyekből álló sort találtunk. A torony alapfala metszette az egyiket, így attól mindenképpen korábbiak. Leletanyag híján akár őskori akár középkori sövényfalú épület cölöpsora lehet.

67 Hasonlóan a korábban a várral foglalkozó tanulmányok szerzőihez, magam is a tornyot gondolom a vár legkorábbi részének. Ugyanakkor azt is hangsúlyozni kell, hogy erre semmilyen konkrét régészeti bizonyítékunk nincs. A torony falaival más falak nem érintkeznek, és nem metszenek más jól datálható középkori objektumot sem. cm széles kőalapozás volt. A téglafal kívül-belül 20-20 cm-rel keskenyebb a kőnél. (A 20. században sajnos müemléktéglákkal szüntették meg ezt a különbséget.) A kb. 22×11×6 cm-es téglák alatt $60-70 \mathrm{~cm}$ szélességben nagyobb, kb. 20-30×15 cm-es kváderkövekből álló sorok voltak, a legfelső kősor (a torony belső oldalán biztosan) kilátszott a földböl. Alatta kisebb 10-20×10-15 cm-es kövek voltak, felül szabályosabban rakva, alatta már csak rendezetlenül, 1-2 tégladarabbal keverve. Ez a réteg a tégláktól $170-180 \mathrm{~cm}$-ig tart. Legalul az alapozási árok több mint két méter mélyen lévő aljára a külső oldalon cölöpöket vertek le, belül tégla és kődarabos réteg volt. A cölöpök a talajvízben megőrződtek, a belölük vett mintákat Grynaeus András vizsgálta meg, sajnos nyárfának és füzfának bizonyultak, dendrokronológiai vizsgálatra nem voltak alkalmasak.

A torony belsejében előkerült a torony földszintjének kövekből kirakott padlójának kevés maradványa. ${ }^{68}$ Szárazon lerakott többféle kőből, közte kemény fehér mészkőből és homokkőből készült. A nagyméretü, kb. 43-44 $\mathrm{m}^{2}$-es belterü torony alkalmas volt lakóterek kialakítására is, a kezdeti időkben lakótoronyként szolgálhatott.

A várudvaron egy vörös színű, letaposott téglaporos réteg kapcsolható a korai időszakhoz, amely a várudvar északkeleti és délnyugati részén valamint a későbbi palotaszárnynál is megfigyelhető volt. A réteg a legkorábbi építkezésekhez is kapcsolódhat. Nem egyenes, hanem lejtős, még őrzi a domb eredeti alakját. Alatta nem találtunk leleteket, felette kevés 13-14. századi kerámia volt.

A torony keltezése és a vár születésének ideje továbbra sem adható meg biztosan. Általában a 14. század első felére szokták keltezni, de ebben az okleveles adatok téves értelmezése is szerepet játszhatott. Egyelöre biztosan csak annyit tudunk mondani, hogy

68 A padló egy másik részletét a Magyar Kálmán által vezetett feltáráson is kibontották, felette késő középkori feltöltést találtak. (Magyar 2004. 190) 


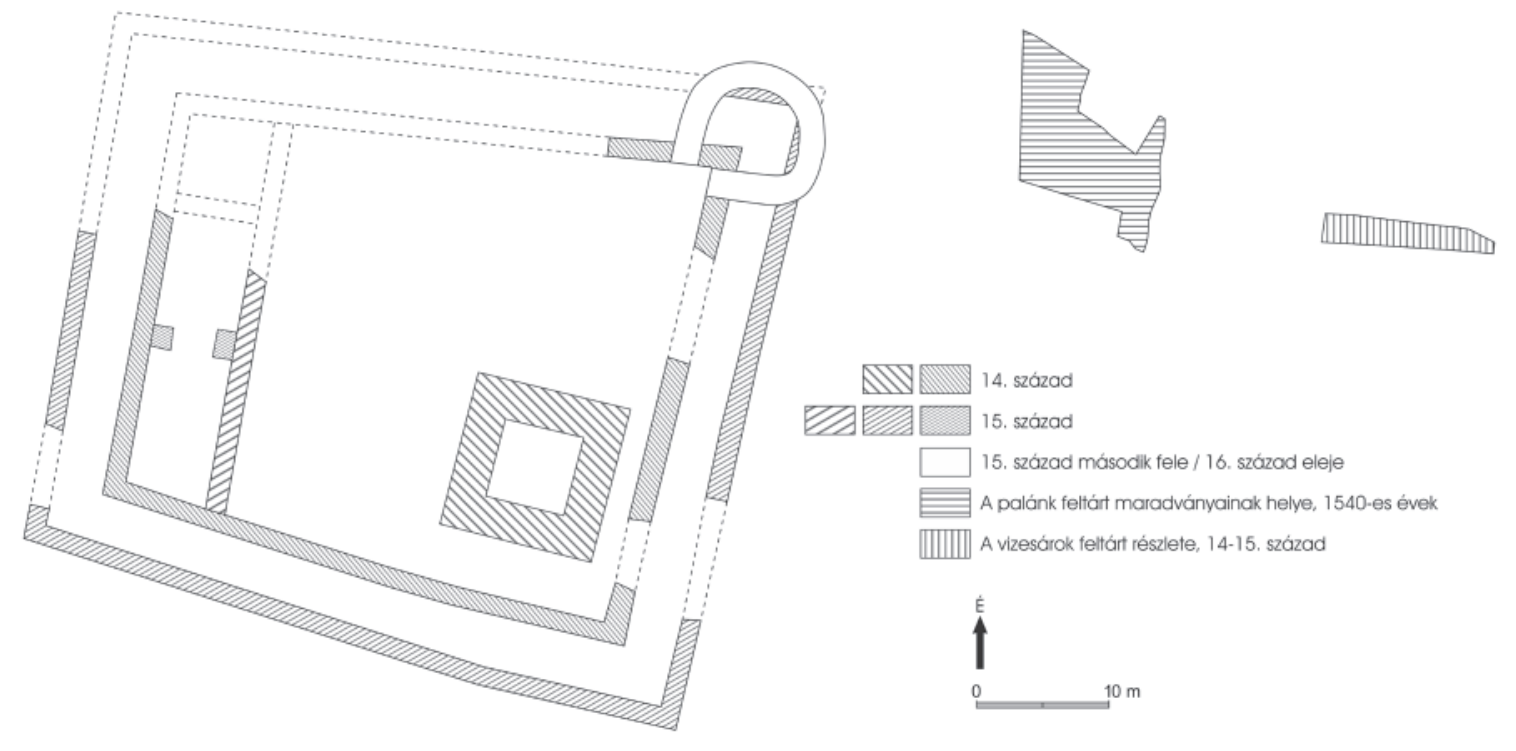

15. ábra. A vár építésének korszakai.

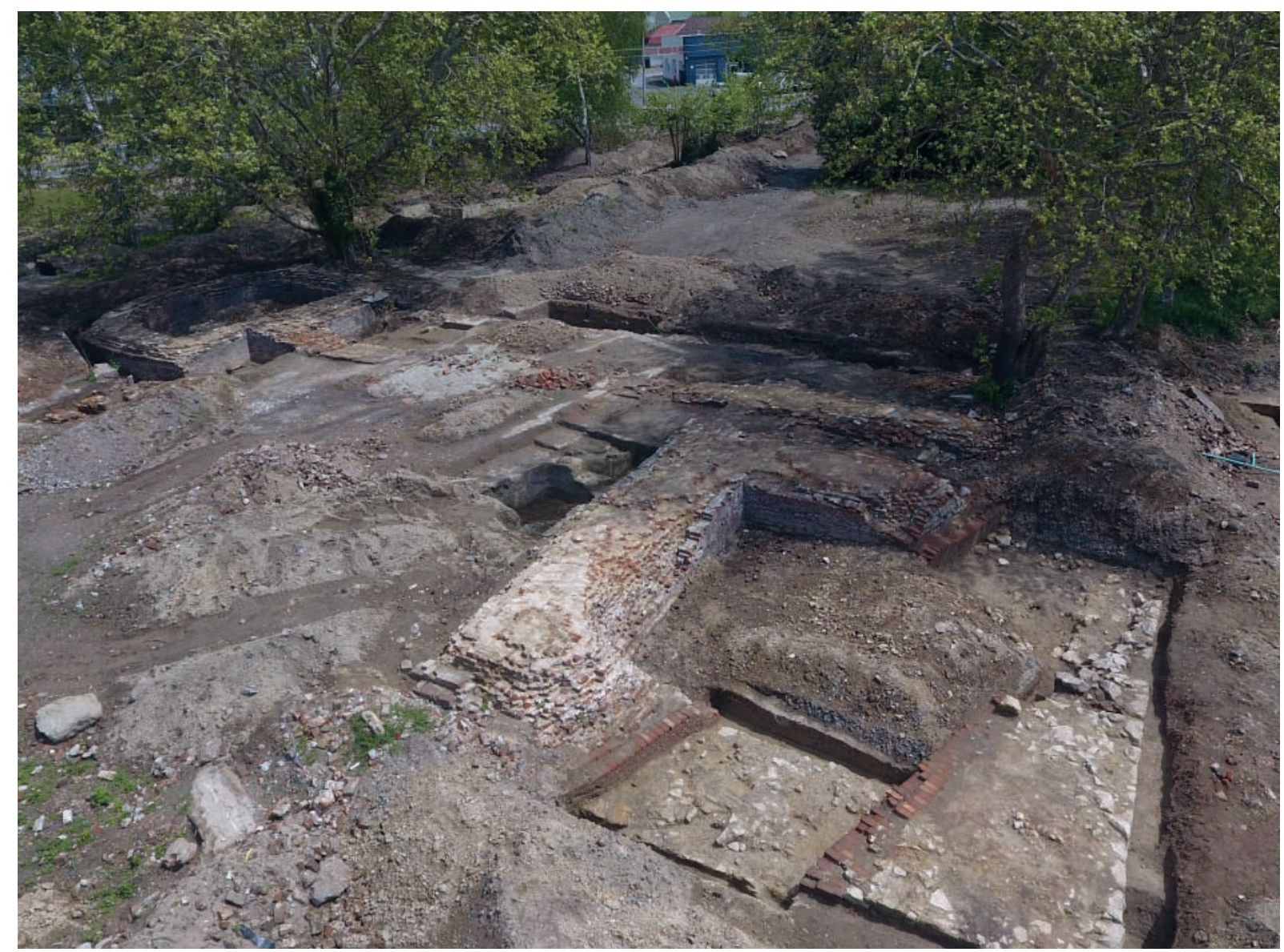

16. ábra. A vár tornyainak maradványai (készítette Borzavári Balázs). 


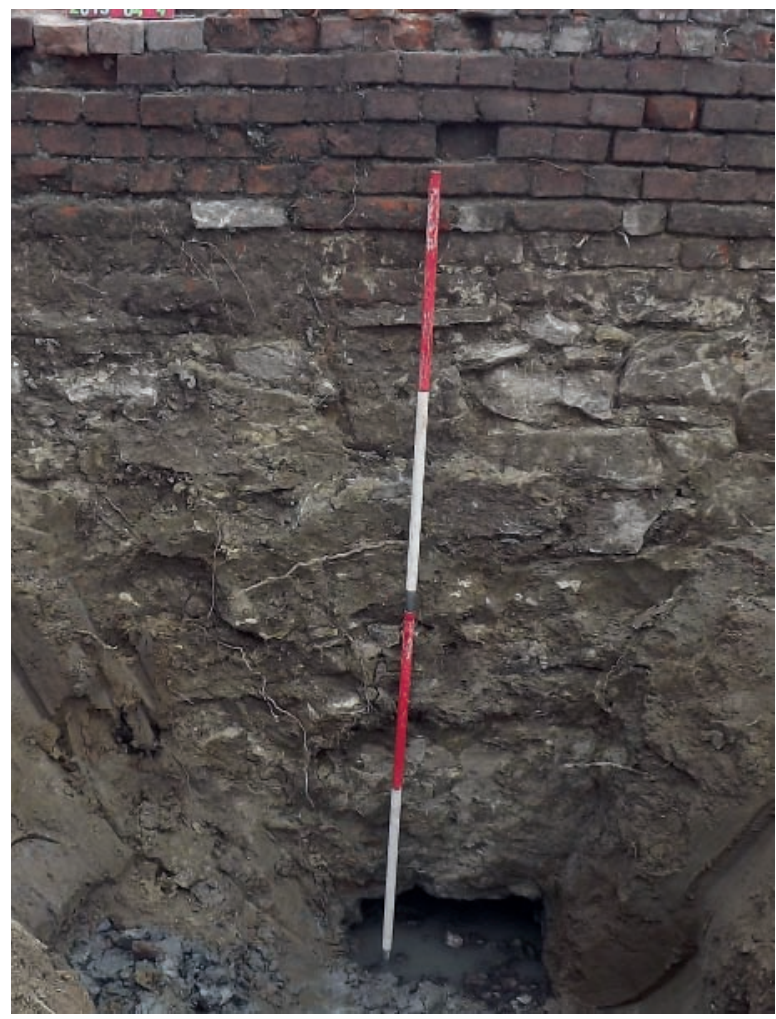

17. ábra. A fötorony alapozása.

a vár és a torony 1387-ben már létezett. Véleményem szerint, építése nem is sokkal előzhette meg első említését, de egy korábbi keltezést sem zárhatunk ki teljes biztonsággal.

Még a korai időszakban a várudvart egy 1,5 méter széles fallal vették körül, amely 15-20 cm-es faragott kövekkel volt alapozva. A felmenő falakat 24$25 \times 12 \times 6-7 \mathrm{~cm}$-es téglákból rakták. A déli oldalon a fal vonala kissé ívelt. $35 \times 37,5$ méteres, szabálytalan trapéz alakú várudvart alakítottak ki. A torony a bezárt terület délkeleti sarkához közel állt.

Két halvány jele van annak, hogy a fal a toronynál valamivel - bár feltehetően nem sokkal - később épült. Erre utal egyrészt tégláinak nagyobb mérete, valamint, hogy az említett korai járószintet egy kis szakaszon a fal északi oldalán kívül is megfigyeltük, ami arra utalhat, hogy volt egy időszak, amikor a várudvar már létezett, de a téglafal még nem. (Utóbbira az is magyarázat lehet, ha a réteget a fal építéséhez kötjük.) Természetesen ebben az esetben a tornyot és az udvart valamilyen könnyebb szerkezetű, fából készült fallal kellet körbevenni, de ennek eddig semmilyen nyomát nem találtuk meg.

1387-ben a torony körül már a várudvart körbevevő téglafal, de még egy egyszerűbb fából készült kerítőfal is állhatott. Akár már a vár életének legkorábbi szakaszában áshatták a vár keleti falától kb. 40-re lévő, legalább 12-13 méter széles vizesárkot. Alját a talajvíz miatt nem találtuk meg, de több mint $2 \mathrm{~m}$ mélységéig volt követhető. $A z$ árokkal a várnak helyet adó

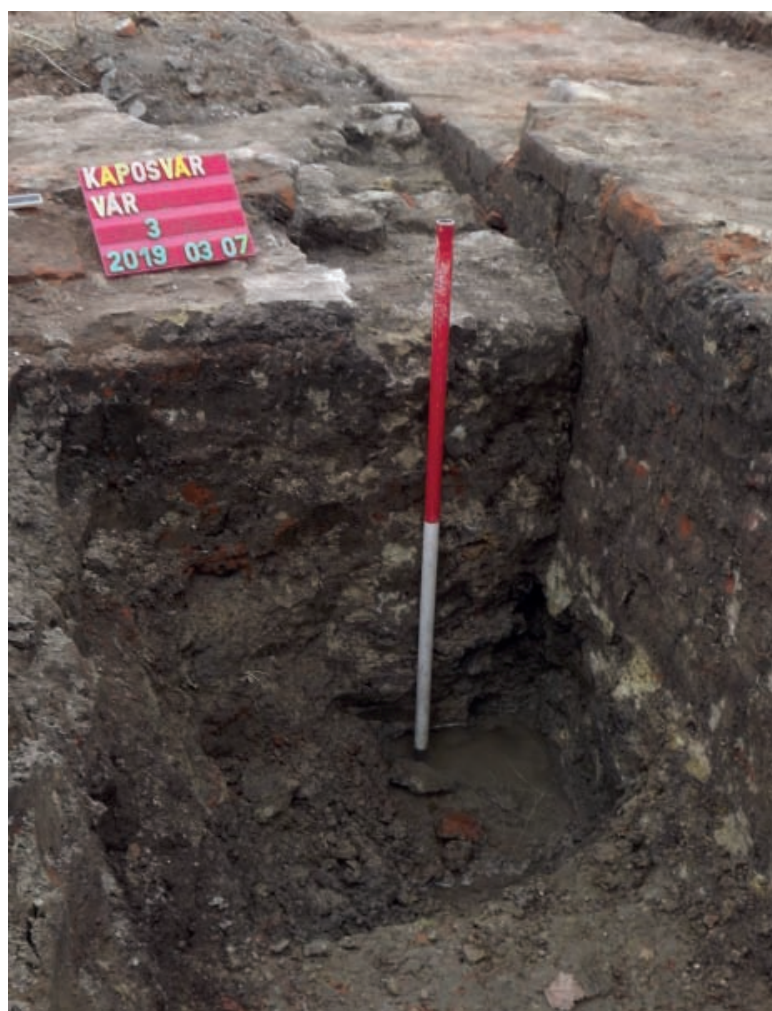

18. ábra. A várudvart körbevevő fal és a palotaszárny kialakításakor hozzáépített fal találkozása.

szigetet vágták át, így a várat mindenhol víz övezte.

A várudvar DNy-i oldalán, (a későbbi palotaszárnyon belüli és kívüli területen is), a korai járószint feletti sárgás feltöltésen, egy szárazon lerakott tégladarabokról kialakított vízszintes járószint hiányos, szétrombolódott maradványait találtuk meg. A téglaréteg a téglafallal körbevett zárt várudvar kiépülése után, de a palotaszárny kialakítása előtt készülhetett. A várudvar más területein nem találtuk nyomát, ott sem, ahol a bolygatások mélysége alapján meg kellett volna maradnia. A tégladarabokkal kirakott felület északi vége az újkori rombolások miatt pontosan nem megadható, nagyjából 4-5 méter széles lehetett, a hossza legalább 12 méter volt. Esetleg csak a várudvar délkeleti sarkát rakták ki valamiért tégladarabokkal, de valószínübb, hogy valamilyen könnyebb szerkezetű (pl. fából épült) épület később jórészt megsemmisült padlószintje volt, ugyanakkor ilyen épület egyértelmü nyomát nem figyeltük meg.

Feltehetően valamikor ebben az időszakban nagyjából vízszintesre alakították a várudvar többi részét is. A toronytól északra sárgás ledöngölt téglás rétegen alakítottak ki egy habarcsos szintet. Mind a délnyugati téglarétegen, mind a torony belsejében, mind a toronytól északra leégés nyoma látszott. A toronyból, a trapéz alakú várudvart körbevevő falakból és a várudvaron álló könnyebb szerkezetű épületekből álló várban tűzvész pusztíthatott. Ha az égett rétegek egykorúak, ez már inkább a 15. században történhetett. A tüz után a torony földszintje új padlót kapott. 


\section{A vár a középkor végén}

$A$ vár legvédettebb nyugati részén egy palotaszárnyat alakítottak ki. A palota padlójánál korábbi feltöltés leletei és egy kemencemaradvány alapján, ez már a 15. században történt. Egyelöre nem tudjuk megmondani, hogy a század első felére (a Tamási-Szerdahelyi közös birtoklás időszakára) vagy a század közepére, második felére (az Újlaki időszakra) tehetjük az építkezést. A vár nyugati falától 6-6,5 méterre keletre egy párhuzamos, 150-160 cm széles falat építettek a vár déli és északi fala közé (18. ábra). A fal alsó része kőből, a felmenő falai téglából épültek. Téglái 23-24×12×5-6 cm-esek.

A palotaszárny szerkezetéről nagyon keveset tudunk. Egy 1931-ban, a még úgy-ahogy látható maradványokról készült - sajnos számos pontatlanságot tartalmazó - felmérés a nyugati szárnynál egy osztófalat jelölt. (Sajnos a területet a Nostra gyárépületet teljesen megsemmisítette, így mi már nem találtuk nyomát.) A 1,5 méteresnek rajzolt fal a palotaszárny északi végét, egy nagyjából $6 \times 6$ méteres négyzet alaprajzú területet választott le. Ekkor itt volt a vár északnyugati sarka, egy helyiség mellett, akár egy kisebb tornyot is kialakíthattak.

Az északon leválasztott résztől délre megmaradt területet nagyjából megfelezik a déli faltól 10,4 méterre épült pillérek. Ezek később épültek a falak belső oldalához, boltívet és emeletet tarthattak. A külső oldalán szabályosan rakott, belül habarcsba dobált téglából készült alapozásuk 1,7×1,4 méteres. A palotaszárny alsó szintjéhez tartozó padló a mai felszínhez közel volt, az újkori földmunkák jórészt megsemmisítették, csak két kis szakaszát találtuk meg. Szorosan egymásmellé tett, szárazon rakott téglából készült. $A$ délnyugati részen talált korábbi járószintnél kb. 40 cm-rel magasabban, a palotaszárny téglából épült felmenő falának indulásával egy szintben volt.

Következő lépésben a várudvart körbevevő falaktól 3,6-3,8 méterre $150 \mathrm{~cm}$ széles falat építettek. Ennek az alapozása és felmenő fala is $25 \times 12 \times 13 \mathrm{~cm}$-es téglából épült.

A fal párhuzamos a korábbival, de a déli oldalon erősebben törik meg vonala. A falszorost alkotó két falgyürü között mindenhol magasan megtaláltuk a bolygatatlan rétegeket ugyanakkor a külső falon kívül már mindenhol a talajvíz mai szintje alatt is bolygatva volt a talaj, ami arra utal, hogy a külső falon kívül árkot áshattak. A keleti oldalon a fal mellett olyan feltöltési rétegeket találtunk, amelyeket vágott egy a faltól 3-4 méterre kiásott árok. Feltehetően a fal tövében ásott árok elkezdhetett feltöltődni, majd megújításra került. Az árok 10-12 méter széles „száraz” árok lehetett, amelybe nem vezettek be a mocsár vizét, de a magas talajvíz miatt, víz álhatott az alján.

Később a vár északkeleti sarkán torony épült. A vár sarkán lévő falszakaszokat visszabontották és nagyrészt ezekre alapozták a torony 2-2,3 méter széles falait ${ }^{69}$ (19. ábra). A kb. 6,5 méteres belterü torony nem

69 A torony belsejében megtalált visszabontott falmaradványok miatt, feltételeztek egy korábbi „sokszögű” tornyot is. A falmaradványok valójában a külső falakhoz tartoznak, korábban nem állt itt torony. (Magyar 2004. 190-192.) volt szabályos kerek, a belső oldalain (nyugaton és délen) falai nagyjából egyenesek, míg kívülre eső részén (északon és keleten) íveltek voltak, csak kisebb mértékben, kb. 1,5 méterre lógott ki a falak síkjából. A téglái $30 \mathrm{~cm}$-esek, nagyobbak a korábbiaknál. Az alapozási árkába talált leletanyag alapján is a 15 . századtól keltezhető a torony. Inkább már a század második fele, a 16. század eleje a valószínű építési ideje. ${ }^{70}$

A torony megépítését a vár kapujának védelméhez lehetne kötni, de a kapunak egyértelmű nyomát nem találtuk meg. Evlia Cselebi leírása szerint keletre nézett a belső vár nagykapuja. A 18-19 században is keletről volt megközelíthető a terület, itt volt az Eszterházy majorság majd a Nostra gyárudvarának bejárata is.

2020-ban a vár déli oldalának közepén a két falgyürü között két merőleges alapfalat találtunk. A sárga habarcsba tett téglából készülő alapozások egy a falszorosba beépített kb. $5 \mathrm{~m}$ belterü építményhez tartoznak.

A sziget keleti részéről keveset tudunk, biztosan vizesárok és legalább a 15. század végén palánkfal védte. Alkalmas volt arra, hogy itt gazdasági épületek, mühelyek esetleg a vár személyzetének egy részének lakóhelye alakuljon ki, ideiglenesen nagyobb létszámú katonaságot is elszállásolhattak itt. A szárazfölddel a szigetet hosszú híd vagy híddal kombinált töltésút köthette össze.

$A z$ 1495-ös ostrom kapcsán Bonfini három vizesárokról valamint utolsó sáncról, és kerítésről írt. A három árok a szigetet a szárazföldről elválasztó víz, a szigetet kettévágó vizesárok és a várfalakat kerítő árok volt. Az árkoknál fából készült palánkfalak is álltak, az „utolsó” jelző arra utal, hogy ebből is három lehetett. A 15. századi palánkfal nyomát az ásatáson nem találtuk meg, lehet máshol állt, részleteit esetleg még felhasználhatták a későbbi palánkhoz, de el is pusztulhatott addigra. Pontos szerkezetét sem ismerjük, egysoros cölöpkerítés, de szélesebb többsoros palánk is lehetett.

Kaposújvár vagy Kaposvár nevü település nem létezett, a környező falvak, Omak, Kecel népe, mesteremberei szolgálhatták ki a várat. Néhányan a várhoz közelebb is letelepedhettek, Omak központja eleve nem is lehetett messze a vártól. Mivel a falvak már a vár megépítése előtt évszázadokkal léteztek természetesen a nevüket sem a várról kapták, de funkcionálisan betölthették azt a szerepet, amit egy vár mellett kialakuló település.

\section{A vár a török korban}

A török veszély miatt a várat tovább erősítették, az 1540-es években építhették a téglavár köré húzott belső palánkfalat. Ekkor már nagyobb létszámú katonaság állomásozott itt, nekik is egy nagyobb területet kellett keríteni, amelyre a sziget vizesárokkal leválasztott keleti, északkeleti fele volt alkalmas.

A vár köré épített palánkfal egy nagyobb szakaszát is megtaláltuk a téglavár északkeleti tornyától kb. 15 méterre. Szerencsére a talajvíz a faszerkezet alsó részét is konzerválta. A földben kb. 10 méter szélességben követték egymást a cölöpsorok, amelyeket

$\overline{70}$ Sajnos a torony belsejét már a 30-as években teljesen átforgathatták, régészeti korú réteget gyakorlatilag nem találtunk benne. 


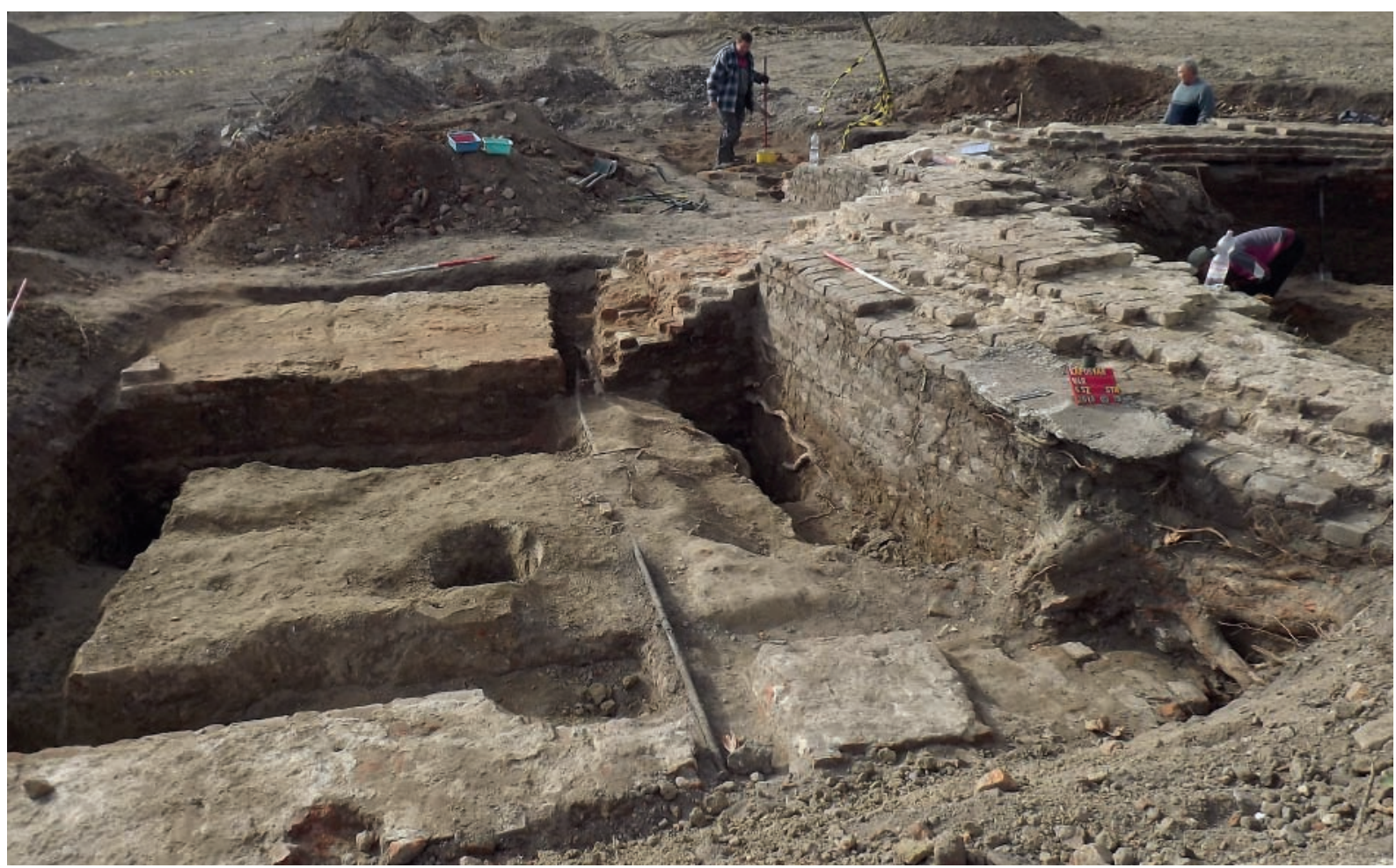

19. ábra. A vár északkeleti falai és az északkeleti sarokra később épített torony maradványai.

megfontak és néhol meg is csapoltak (20., 21. és 22. ábra). Néhol csak az egymástól 60-100 centiméterre lévő cölöpök látszottak ki a magas talajvízből, de több helyen megtaláltuk a nekik ásott $60-80$ centiméter átmérőjü ovális gödröket is. A cölöpök mérete változatos, általában 25-40 centiméter átmérőjűek, az első sorban $50 \mathrm{~cm}$-es, míg föleg a hátsó részeken vékonyabb, 10-20 centiméteres darabok is voltak. Több helyen 3-5 centiméteres karókat találtunk a nagyobb cölöpök között, amelyek a fonatot támaszthatták. A külső cölöpsornál farkasfog-szerüen elhelyezett gerendákkal csapolták meg a cölöpöket, hasonlót figyeltünk meg kb. 6 méterre nyugatra a 6-7. soroknál is. A 9. sor cölöpjeit egy nagy széles gerendával csapolták meg. Ez és a tőle kb. 9,5 méterre lévő első sor között, a közbülső cölöpsorokba is bekötve, hosszú gerendák feküdtek, amelyek a szerkezetet stabilizálták. A felettük lévő döngölt, kemény, agyagos réteget $60-80 \mathrm{~cm}$ vastagságban találtuk meg. Több helyen megfigyelhető volt, hogy a mocsaras talaj miatt vesszőfonatot, vékony deszkasort tettek le, majd erre döngölték a palánk földjét, néhol tégladarabokat is tettek a gerendák alá.

A faszerkezet tölgyfáiból dendrokronológiai vizsgálatra mintákat vettünk, amelyeket Grynaeus András vizsgált meg. A vizsgálat eredménye alapján az egyik gerendát 1546-ban vagy valamivel később vágták ki. Ez alátámasztja sejtésünket, hogy a palánk a török hódítás előtt, feltehetően az 1540-es években készült.

A palánk külső cölöpsora előtt egy szükülő falú, felül $3 \mathrm{~m}$ széles árok volt. Ebben ferde helyzetű, kifelé néző karók voltak, amelyek ki lehettek hegyezve és az ostromlók távoltartását szolgálták. A palánkfal hatékonyan állította meg az ágyúgolyókat, a külső cölöpsornál és az előterében, az árokban tucatnyit találtunk.

Keleten, északkeleten a palánk nagyjából 15 méter távolságból keríthette a téglafalakat. Sajnos a korábbi építkezések, feltárások során előkerült cölöpök pontos helye már nehezen rekonstruálható a korábbi beszámolókból, de úgy tűnik a többi oldalon is a falaktól nagyjából hasonló távolságra találtak cölöpöket. A 2020-ban viszont azt tapasztaltuk, hogy a déli oldalnál a palánk a téglafalakhoz közel futott, aminek a Kapos közelsége lehet az oka.

A téglavár északkeleti sarkától keletre feltárt palánkfalak iránya dél felé haladva kissé eltart a téglafalaktól. A két évben összesen nagyjából 30 méter hoszszan tudtuk megfigyelni a 10 méter széles palánkfal talajvíz által konzervált alsó részét. Ettől délebbre erősen rombolva van a terület, így a vonala nem teljesen rekonstruálható, de úgy tủnik egy szakaszon már téglafalakhoz valamivel közelebb futhatott a palánk külső oldala. Északkeleten így a fal vonalának megtörésére, fülszerü kiugrásra, esetleg valamilyen egyszerübb korai bástyaformára gyanakodhatunk. A téglafal és a belső palánk között a kezdeti időszakban itt még meg lehetett a középkori árok. A vár délkeleti sarka felé nyitott szelvényünkben majdnem a téglavár délkeleti sarkáig, 25-27 m hosszan sorakoznak a cölöpök, aminek az lehet az oka, hogy a délnek kanyarodó palánkfalat fogtuk meg. Itt a középkori árkot, már hamar be kellett tölteni. A déli oldalon a téglafalhoz közel, azzal párhuzamosan futott a palánkfal. 


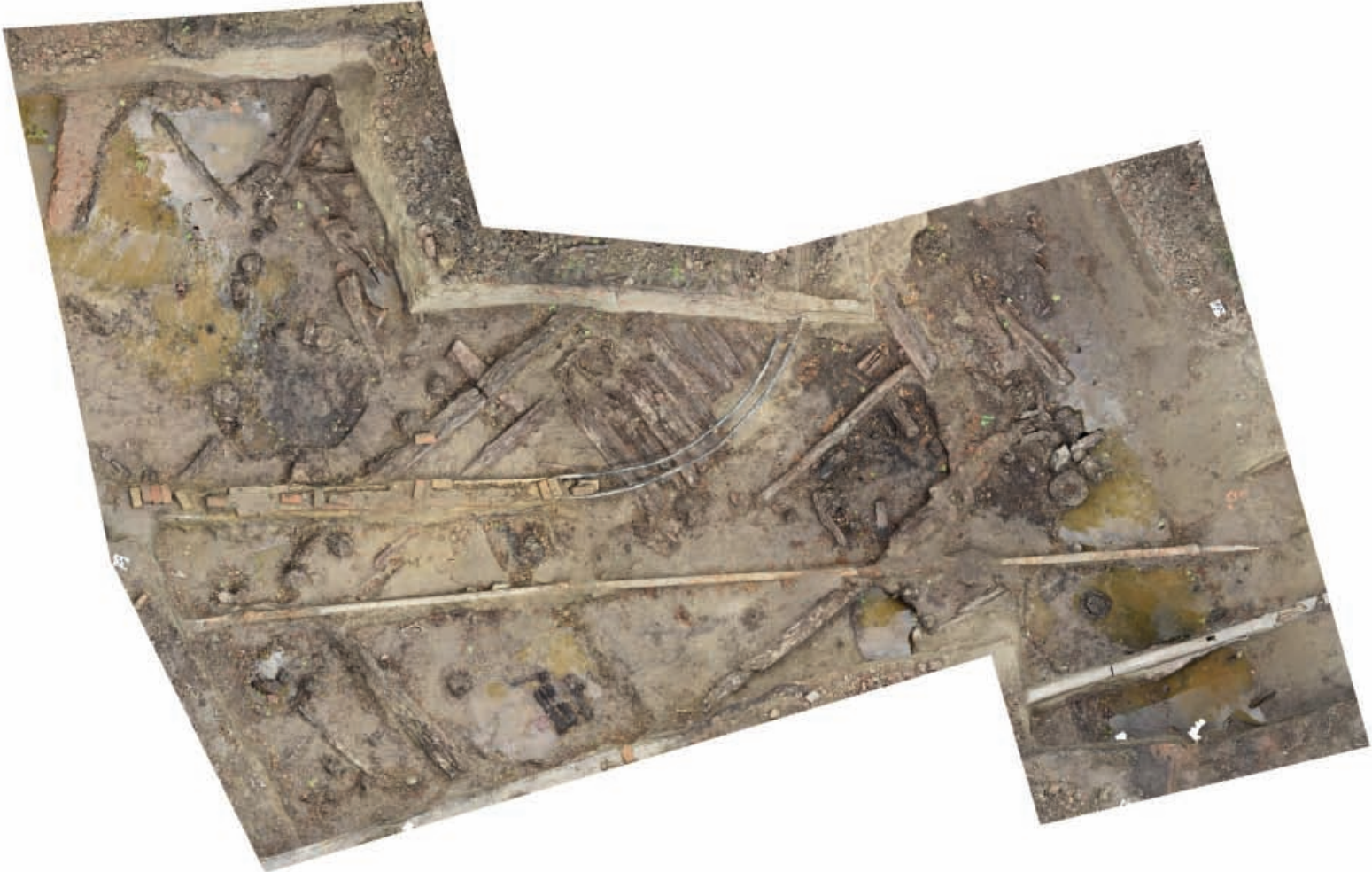

20. ábra. A palánk maradványairól készült felmérés részlete.

(A felmérést a Pazirik Kft készítette, önzetlen segítségüket ezúttal is köszönöm!)

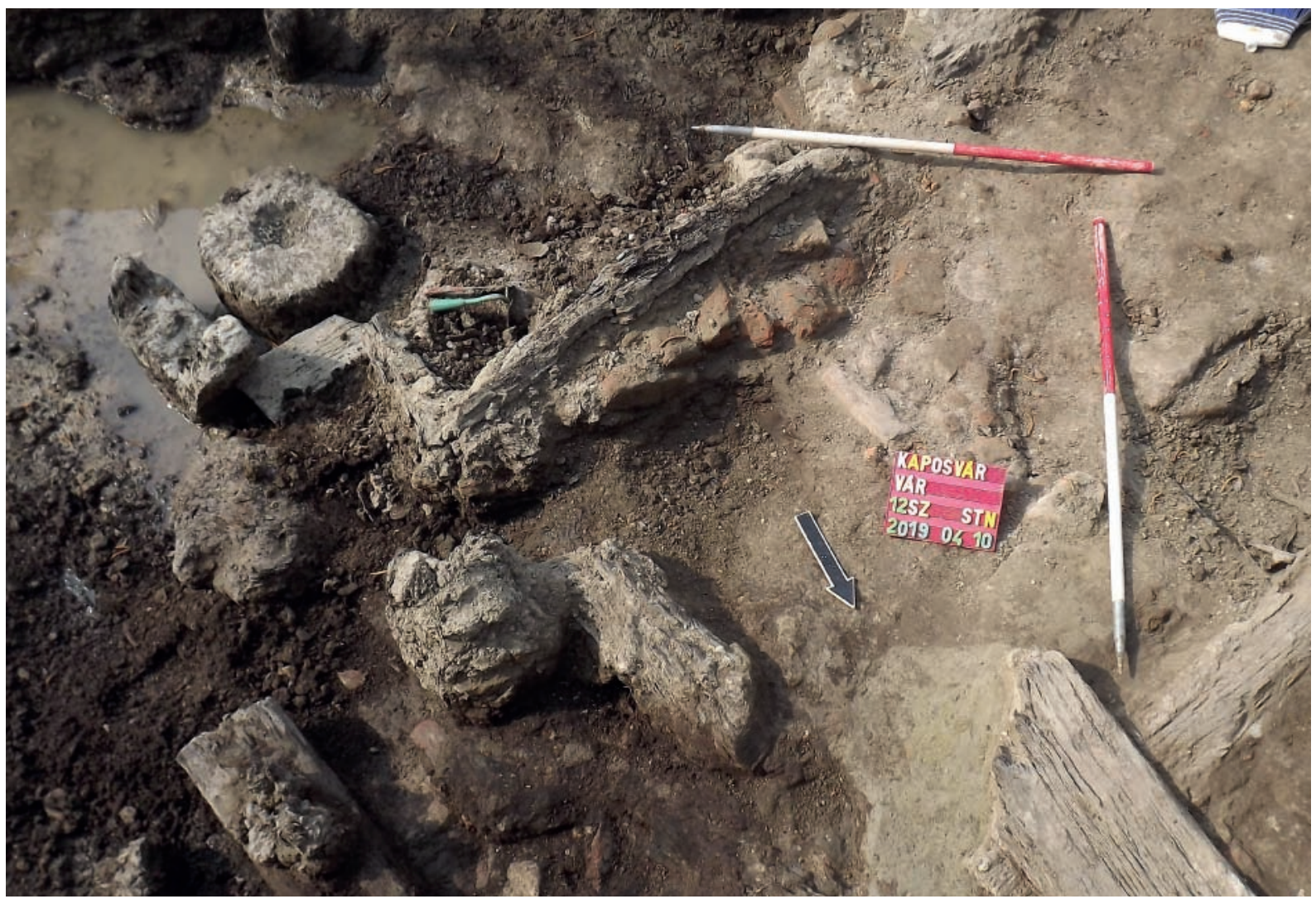

21. ábra. Megcsapolt faszerkezet maradványa a palánk külső cölöpsoránál. 


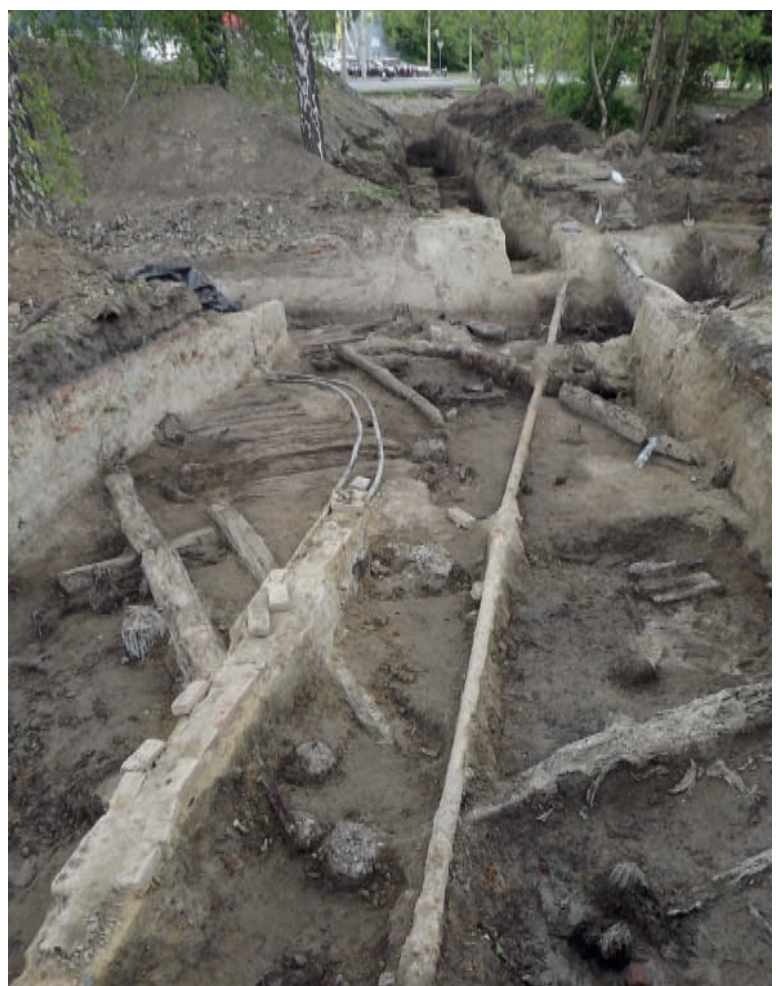

22. ábra. A palánk újkori vezetékek által rombolt maradványai a belső oldal felöl fényképezve.

A sziget nyugati felén lévő külső palánkról kevesebbet tudunk, a palánkfal húzódhatott a víz szélén vagy valamivel bentebb is. A Vár utca nyugati részén és a benzinkútnál talált cölöpök ${ }^{71}$ ide tartozhattak. A külső palánk tehát nem vette körül mindenhol a belső várat, csak attól keletre, északkeletre húzódott.

A belső palánkot a török foglalás után folyamatosan újítgatták, erre utal a talált leletanyag, de a betöltésben és a faszerkezet maradványain is látható ennek számos jele, így pl. a külső oldal megújított részén már nem csapolták meg a cölöpöket. A Grynaeus András által végzett dendrokronológiai vizsgálat eredménye alapján a külső cölöpsor megújított, már nem csapolt cölöpsorából származó cölöp kivágásának legkorábbi lehetséges időpontjaként az 1616. évet adta, ami már a török uralom alatti javítgatás nyoma. A belső oldalon meg is szélesítették a palánkot. A téglavár körüli, palánkon belülre került árkot már a törökök betölthették, a rajta tégladarabokból járószintet alakítottak ki.

$A$ belső várban biztosan török épület nyomát nem ismerjük. A délkeleti sarokban a középkori falak közé két lépcsőben egy újkori épület épült. Ennek északabbi helyisége mindenképpen a 18-19. században épült, esetleg a déli részénél gondolhatunk török kori eredetre a Magyar Kálmán vezetett feltárás során itt talált leletanyag alapján. ${ }^{72}$

71 A benzinkútnál elökerült cölöpökről: Magyar 2004. 192.

72 Magyar 2004. 190. A délkeleti sarokban kialakított korábbi helyiség esetleg a megmagyarázná a Manone féle rajzon látható délkeleti négyzetes tornyot, de a középkori falak közé beépített fal elég gyenge minőségü és ferde helyzetü.
A sziget keleti részén, a korábban a magyar katonaság által belakott külső palánkon belül alakulhatott ki a muszlim városrész. A kamarai összeírásban leírt hosszú utca feltehetően a kifli alakú terület hossztengelyében, ívelten húzódott.

\section{A külváros}

Erödített városra csak a török kortól van biztos adatunk, ekkor palánkfallal körbevett, rácok és katolikusok lakta városrészt említettek. Ez már nem fért el a szigeten, attól keletre, északkeletre, a mai belváros felé lehetett. A török kori városnak nem sok közvetlen kapcsolata lehetett a korábban valahol a közelben lévő Omakkal. Utóbbi a forrásokból az 1540-es években eltủnt, a vár ostromakor sem említettek települést a vár mellett, a falu ekkorra elpusztulhatott. A török korban föleg a Balkánról érkezett lakosokkal alakult ki az új település, amelyet a források városkának említenek, ${ }^{73}$ tehát elég kicsi lehetett. $A$ városka biztos nem ért át a Kaposon, ahogy utaltam rá a kataszteri térképek alapján nagyjából sejthető a nyugati északi és déli határa.

A várost délről a Kapos és széles ártere, nyugatról a Kapos és a bele futó vízfolyás (a mai Malomárok előde) és a berek határolta. A berek északon túlnyúlt a vízfolyáson, a mai Városliget és a Malomároktól keletre lévő áruházak által elfoglalt terület is víz alatt volt. A várost így északi oldalán is részben a berek határolta.

A török kori városka keleti határát legtöbbször a Berzsenyi utcáig, a Plázáig valószínűsítették, míg Tímár Péter a mai Kossuth térre tette. A régészeti adatok egyelőre nem segítenek megválaszolni a kérdést. ${ }^{74} \mathrm{~A}$ város néhány objektumát Magyar Kálmán tárta fel a Plázától délre lévő telken. A városban itt-ott előkerült famaradványok is nehezen értelmezhetőek, mert nem csak a palánkfalak épültek faszerkezettel, de a házak, hidak és utak is. Az Ady utca nyugati végénél talált útként azonosított famaradványok ${ }^{75}$ lehetnek akár a városfalon belüli akár azon kívüli út maradványai.

Az egykori felszín a jelentős, több méteres feltöltődés miatt pontosan nem rekonstruálható, de az Ady Endre utca ma is erősen nyugatra lejt, a múltban ez még inkább így lehetett. Ha a város határa a Berzsenyi útnál volt, az árokban víz folyhatott, míg a mai Kossuth térnél inkább már csak száraz árok lehetett. A földrajzi helyzet alapján leginkább a Berzsenyi és Ady Endre utca találkozásához valószínüsíteném a város keleti végét, de biztosan csak további kutatások után lehetne mondani.

A hányatott sorsú, majdnem teljesen megsemmisült várral kapcsolatban a legkedvezőbb változás a beleépült gyárépületek 2018-ban történt elbontása volt. A tervek szerint a területen egy parkot fognak kialakítani, ahol a vár téglafalak maradványai is megtekinthetők lesznek.

\footnotetext{
73 Hoss 1949. 9.

74 A múlt század elején a Berzsenyi útnál állítólag megtalált kapumaradványokról szóló beszámolók nem ellenőrizhetőek.
} 75 Költő 1999., Magyar 2008. 


\section{Irodalom}

BAsıcs B. 2002: A török kori várábrázolások hitelességének kérdése. In: A Hódoltság régészeti kutatása. Budapest, pp: 43-50.

BonfINI, A. 2005: A magyar történelem tizedei. (ford. Kulcsár Péter) Budapest 1995.

DEÁK VARGA D. 1993: Hol rejtőzik Kaposvár vára. Somogy Megye Múltjából - Levéltári Évkönyv 24: 31-46.

DÉNES J. 2015: Kaposvár török kori felmérése. - Djnaplója blog 2015 https://djnaploja.wordpress.com/2015/03/08/kaposvar-torok-korifelmerese/

Domokos Gy. 1999: Törökkori várrajzok Stockholmban. Beszámoló a stockholmi Királyi Hadilevéltárban végzett kutatásról. - Hadtörténeti Közlemények 112. (1999 1. sz.): 112-116.

ENGEL P. 1996: Magyarország világi archontologiája 1301-1457 I-II. Budapest.

CseleBI, E. 1908: Evlia Cselebi török világutazó magyarországi utazásai. II. 1664-1666. Fordította, jegyzetekkel ellátta Dr. Karácson Imre. (Török-magyar kori történelmi emlékek. II. Írók.) - Budapest, 1908.

FELD I. 2014: A magánvárak építésének kezdetei a középkori Magyarországon a régészeti források tükrében. - Századok 148. évf. 2. sz.

FüGEDI E. 1977: Vár és társadalom a 13-14. századi Magyarországon. - Budapest.

GYőRFFY GY. 1975: Kaposvár az Árpád-korban. - In: Kanyar József (szerk.): Kaposvár. Várostörténeti tanulmányok. Kaposvár, pp: 63-73.

Hoss J. 1948: A kaposvári plébánia története. - Veszprém.

KISs G. 1984: Török hadak Magyarországon 1526-1566. Kortárs török történetírók naplórészletei. Fordította Thury József, fordítását válogatta, jegyzeteit bővítette Kiss Gábor. Budapest.

KISARI BALLA GY. 1996: Török kori várrajzok Stockholmban. Budapest 1996.

KомJÁTHY M. 1975: A középkorvégi Kaposvár. - In: Kanyar József (szerk.): Kaposvár. Várostörténeti tanulmányok. Kaposvár, pp: 75-92.

KöLTŐ L. 1999: Kaposvár, Ady Endre 15. - In: Marton Erzsébet és Kisfaludi Júlia (szerk.): Régészeti kutatások Magyarországon 1999. Budapest 2000. p. 215.

KUBINYI A. 1973: A kaposújvári uradalom és a familiárisok szerepe Újlaki Miklós birtokpolitikájában. (Adatok a XV. századi feudális nagybirtok hatalmi politikájához) -Somogy Megye Múltjából, Levéltári Évkönyv 4: 3-44

MAGYAR K. 1988: A középkori kaposvári vár és város története. - In:
Laczko András (szerk.): Tanulmányok Kaposvárról. Kaposvári kiskönyvtár 5. Kaposvár, pp: 3-36.

MAGYAR K. 2004: A kaposvári vár területén végzett régészeti kutatások eredményei. -Somogyi Múzeumok Közleményei 16: 187-222.

MAGYAR K. 2007: Kaposvár, Vár utca. - In: Kisfaludi Júlia (szerk.): Régészeti kutatások Magyarországon 2006. Budapest 2007. pp: 13-215.

MAGYAR K. 2008: Kaposvár, Ady Endre utca. - In: Kisfaludi Júlia (szerk.): Régészeti kutatások Magyarországon 2007. Budapest 2008. p. 233.

MAGYAR K. És NovÁKı GY. 2005: Somogy megye várai a középkortól a kuruc korig. Kaposvár.

MANONE, C. 1686: L'Ungheria Vendicata. Milano.

MOLNÁR I. 2019: Rövid beszámoló a kaposvári várnál 2018-ban végzett régészeti feltárásról. Archeologia - Altum Castrum Online 2019. https://archeologia.hu/content/archeologia/641/molnar-kaposvar.pdf

MOLNÁR I. 2020: A kaposvári vár régészeti kutatása 2019-ben. Castrum 2020. Megjelenés alatt

Oross A. 2005: Az 1702. évi Magyarországi várrombolások (tervezet és valóság). Vázlatos áttekintés. - Castrum 2: 89-100.

PANCERI, G. A. 1687: Continuatione de successi nell'Ungheria. - Milano.

RossI, G. G. DE 1687: Teatro della Guerra contro il Turco. - Rome.

SZALAI B. 2001: Magyar várak, városok, falvak metszeteken 1515-1800. I. kötet A mai Magyarország. Budapest 2001.

SZAKÁLY F. 1975: Kaposvár a török időkben. - In: Kanyar József (szerk.): Kaposvár. Várostörténeti tanulmányok. Kaposvár, pp: 93-138.

SzATLócZKI G. 2016: Elfelejtett végvári hősök, Zrinyi Miklós és Szondi György kortársai. - In: Misseles, a 16-17. század hétköznapi történelme. Várháborúk kora blog 2016. https://missiles.blog. hu/2016/03/26/az_elfeledett_vegvari_hosok_zrinyi_miklos_es_ szondy gyorgy kortarsai

SZATLócZKı G. 2016a: Vár a várban. A várak népe és a mezei hadak a 16. század közepén I. A várak népe. - Missiles, Szeged.

TímÁR P. 2016: A Győr nembeli szerdahelyi család története, birtokai és okmánytára. -Szeged.

THURY J. ÉS KISS G. 1984: Török hadak Magyarországon 1526-1566. Kortárs török történetírók naplórészletei. Thury József fordítását válogatta jegyzetekkel bővítette Kiss Gábor.

ZÁDOR M. 1964: Kaposvár. - Budapest.

WALDTMANN, J. J. \& KRAUS, U. 1696: Admirables efectes de la providencia sucedios en la vida de Leopoldo primero ... Milano.

\section{The Castle of Kaposvár}

\section{ISTVÁN MOLNÁR}

Kaposvár Castle was built on an island-like protrusion emerging from the flood basin of the Kapos. The environment due to the water regulations of the 19. C. changed to a large extent, but on older maps the boundaries of the island are predictable. The castle was already standing by 1387 , and was in the possession of various noble families until 1555, while between 1555-1686 fell under Turkish rule. Today the castle entirely perished, on its remains a factory was established and only minor walls survived.

During our excavation conducted in 2019 we tried to locate the still existing remains and to determine the the building periods of the castle. The earliest phase was a $11,8 \times 11,8 \mathrm{~m}$ tower built from bricks with stone base. Later, with the establishment of further brick walls a $35 \times 37,5 \mathrm{~m}$ wide courtyard was formed. The island was devided by ditches. In the earlier phase wooden buildings of lighter structure stood in the courtyard. In the 15. C. a palace wing was formed on the Western part. Outside the walls encircling the court, around 3,63,8 $\mathrm{m}$ further new brickwalls were built, and surrounding a wide ditch was constructed. On the NE-ern corner a tower was installed around the turn of the 15-16. C.

Due to the danger of Turkish attacks in the 1540-s, $15 \mathrm{~m}$ far from the brickwalls palisade walls were formed. Part of this palisade - most probably a bastion was unearthed during the excavation. The lower part of the wooden structure was preserved due to high groundwater. In the ground, lines built up of poles of $20-50 \mathrm{~cm}$ in diameter followed each other around $10 \mathrm{~m}$ wide, and were connected by weaving and tapping. The structure was stabilized by transverse beams, and we could detect that wickers and boards were placed between the lines of poles and the clay was tamped on it. A shrinking, on the top $3 \mathrm{~m}$ wide ditch with outer slanting poles was deepened on the outer side of the palisade. The palisade was constantly renewed during the Turkish rule. 